\title{
New stratigraphic data from the Lower Penninic between the Adula nappe and the Gotthard massif and consequences for the tectonics and the paleogeography of the Central Alps
}

\author{
Federico Galster *, Mattia Cavargna-Sani, Jean-Luc Epard, Henri Masson \\ Institute of Earth Sciences, University of Lausanne, Geopolis, CH-1015 Lausanne, Switzerland
}

\section{A R T I C L E I N F O}

\section{Article history:}

Received 26 November 2011

Received in revised form 23 May 2012

Accepted 29 May 2012

Available online $\mathrm{xxxx}$

\section{Keywords:}

Alpine paleogeography

Helvetic

Penninic

Briançonnais

Continental rifting

Triassic

\begin{abstract}
A B S T R A C T
New stratigraphic data along a profile from the Helvetic Gotthard massif to the remnants of the North Penninic basin in eastern Ticino and Graubünden are presented. The stratigraphic record together with existing geochemical and structural data, motivate a new interpretation of the fossil European distal margin. We introduce a new group of Triassic facies, the North-Penninic-Triassic (NPT), which is characterised by the Ladinian "dolomie bicolori". The NPT was located in-between the Briançonnais carbonate platform and the Helvetic lands. The observed horizontal transition, coupled with the stratigraphic superposition of a Helvetic Liassic on a Briaçonnais Triassic in the Luzzone-Terri nappe, links, prior to Jurassic rifting, the Briançonnais paleogeographic domain at the Helvetic margin, south of the Gotthard. Our observations suggest that the Jurassic rifting separated the Briançonnais domain from the Helvetic margin by complex and protracted extension.

The syn-rift stratigraphic record in the Adula nappe and surroundings suggests the presence of a diffuse rising area with only moderately subsiding basins above a thinned continental and proto-oceanic crust. Strong subsidence occurred in a second phase following protracted extension and the resulting delamination of the rising area.

The stratigraphic coherency in the Adula's Mesozoic questions the idea of a lithospheric mélange in the eclogitic Adula nappe, which is more likely to be a coherent alpine tectonic unit. The structural and stratigraphic observations in the Piz Terri-Lunschania zone suggest the activity of syn-rift detachments. During the alpine collision these faults are reactivated (and inverted) and played a major role in allowing the Adula subduction, the "Penninic Thrust" above it and in creating the structural complexity of the Central Alps.
\end{abstract}

(C) 2012 Elsevier B.V. All rights reserved.

\section{Introduction}

The Alps, as a mountain belt, are the result of Cretaceous convergence and Tertiary collision between European and African derived plates following the closure of oceanic domains (Dewey et al., 1989). Their history, however, starts long time before Cretaceous convergence and experienced periods of extension (Trümpy, 1958).

The pre-orogenic evolution of the Alpine realm leads to the creation and differentiation of several paleogeographic domains whose remnants have subsequently been stacked in the orogenic belt during Tertiary collision (Schmid et al., 1996; Steck, 2008). From an internal (Upper) toward an external (Lower) position the following domains

\footnotetext{
* Corresponding author at: Institute of Earth Sciences, University of Lausanne, Geopolis, CH-1015 Lausanne, Switzerland. Tel.: 41216924444.

E-mail address: federico.galster@unil.ch (F. Galster).
}

are generally distinguished: the Adriatic plate sensu lato in South Alpine and Austroalpine position; the remnants of the Liguro-Piemontese ocean in Upper Penninic level; the nappes and klippes issued from the Briançonnais paleogeographic domain stacked in the Middle Penninic; the remnants of the North Penninic basin and its North margin assembled in the Lower Penninic nappes together with the series originated from the Valais Trough; finally the Helvetic sensu lato domain that is distributed in the Ultrahelvetic and Helvetic nappes and in the external massifs.

This repartition and its paleogeographic significance are not devoid of discussions. Of particular interest and a matter of passionate debates is the role played by the units currently stacked in a Lower Penninic position.

A portion of the Lower Penninic of the Western Alps (the "zone de Sion-Courmayeur-Tarentaise", Valais s. str.) is characterised by a typical lithological association: the "Trilogie Valaisanne" of Cretaceous or younger age (Trümpy, 1951; Trümpy, 1954). This group of facies, that belong to the core of the definition of the Valais s.str., has never been found in the Eastern Alps, where in a Lower Penninic position, there is 
a monotonous package of calcschists, the so called Bündnerschiefer, that during Jurassic and Cretaceous filled the North Penninic basin s.l. (Probst, 1980; Steinmann, 1994).

Based on the presence of MORB-type metamafics, several workers (e.g. Dürr et al., 1993; Steinmann and Stille, 1999) proposed the presence of oceanic crust in the internal North Penninic. Where radiochronologically dated, the supposed oceanic rocks, are of late Middle-early Upper Jurassic time ( $161 \mathrm{Ma}$, Liati et al., 2005). Concerning the Valais Trough, the birth of an early Cretaceous ocean has been proposed (Frisch, 1979; Stampfli, 1993) but has not yet been proven convincingly by the dating of Cretaceous oceanic crust. Where dated, metabasites in the Valais domain s.str. (i.e. zones characterised by the "Trilogie Valaisanne") are Paleozoic (Masson et al., 2008). Moreover a Cretaceous age for the supposed Mesozoic ocean is at odds with the Jurassic age reported for the oceanic crust in the North Penninic.
Currently two hypotheses are the most widely accepted to explain the significance of Lower Penninic units and the connection ValaisNorth Penninic.

The first one considers the North Penninic and the Valais as one domain, located between the Helvetic margin and the Briançonnais domain, that experienced hyper extension during the Jurassic rifting, at the same time that the Liguro-Piemontese ocean opened to the south (Manatschal et al., 2006). The second hypothesis, on the other hand, regards the Valais domain as a Cretaceous transcurrent ocean which opened oblique into the older Liguro-Piemontese ocean to the east and into the European margin to the west, where it separated and isolated the Briançonnais domains from the continent (Stampfli, 1993). In this last scenario the Briançonnais domain is regarded as a far travelled exotic terrane that during the Cretaceous time migrated eastward and duplicated the European margin in the Western and Central Alps (Stampfli et al., 2002).
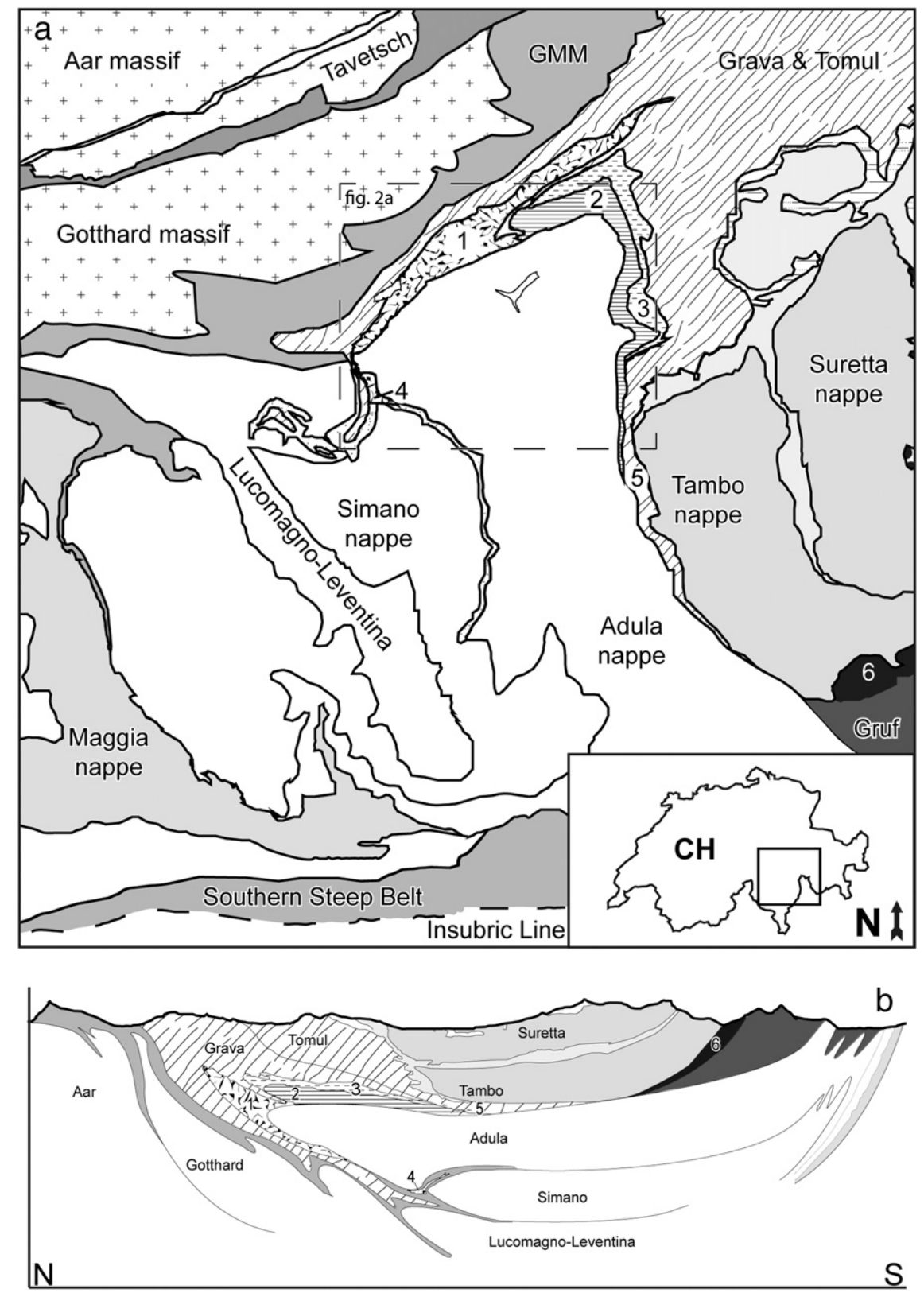

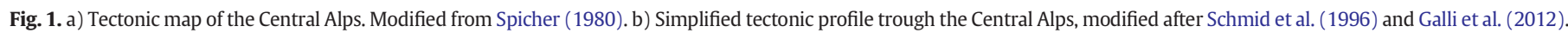
1) Piz Terri-Lunschania zone. 2) Lower and Upper Valser slices. 3) Aul unit 4) Soja unit. 5) Misox zone 6) Chiavenna peridotite. (GMM) “Gotthard-Massivisher-Mesozoikum”. 
In this contribution we will investigate the aspect and the distribution of pre- syn- and post-rift facies on the distal European margin in the Central Alps in order to shed light on the tectonostratigraphic evolution of the North Penninic rifting and to understand the Helvetic-Briançonnais relationship. The refinement of the stratigraphic record coupled with structural and metamorphic information is used as a tool to extricate the extremely complex tectonic around the eclogitic Adula nappe.

\section{Geological setting and background}

The study area is located at the northeastern edge of the Lepontine dome, SW of the Gotthard massif, astride northeastern Ticino and western Graubünden (Figs. 1a and 2a). The tectonic map of the Central Lepontine Alps (Berger and Mercolli, 2006) and its explanatory note (Berger et al., 2007) give a good overview of the geological setting. The Lepontine dome consists of a highly deformed pile of nappes

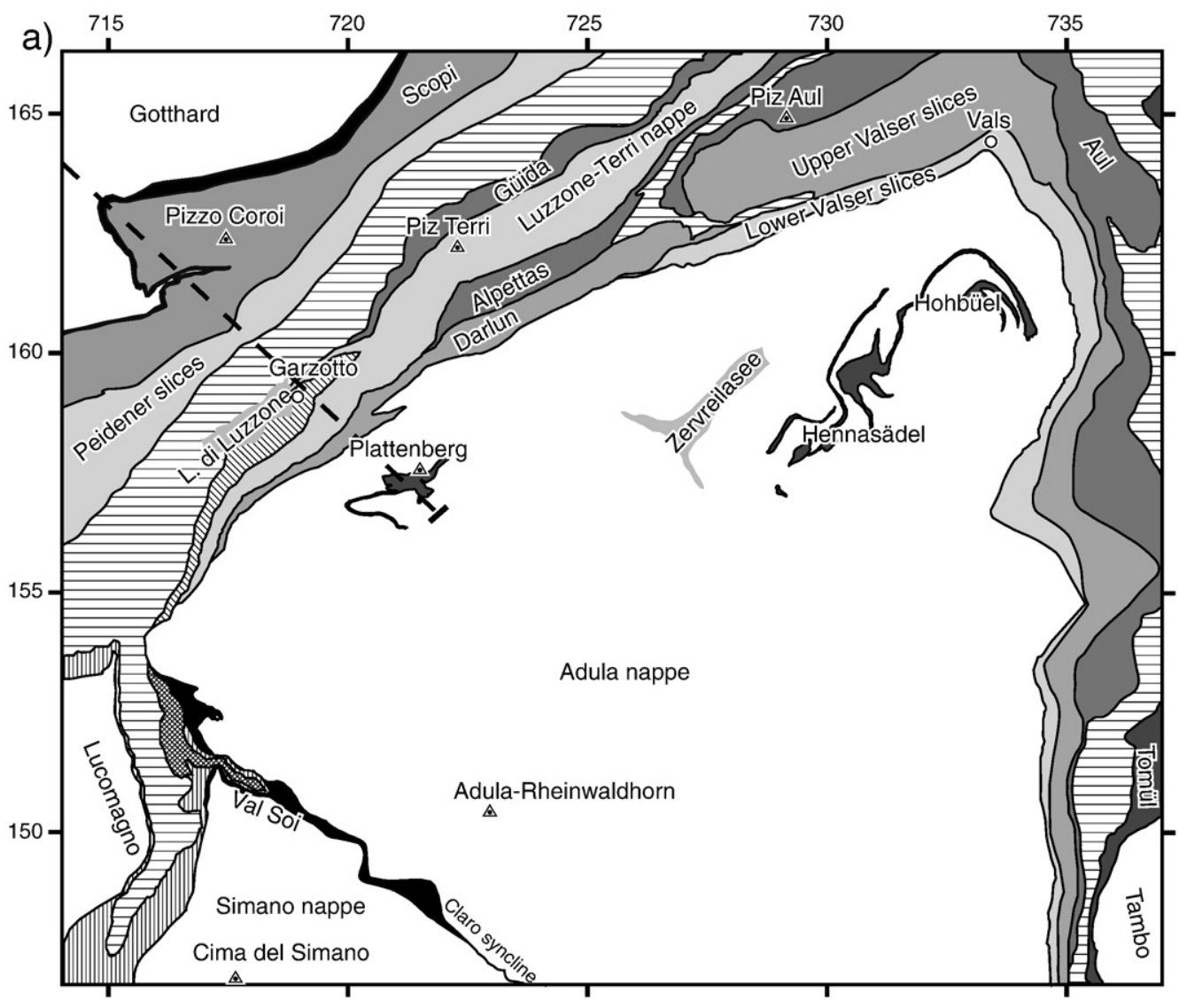

b)

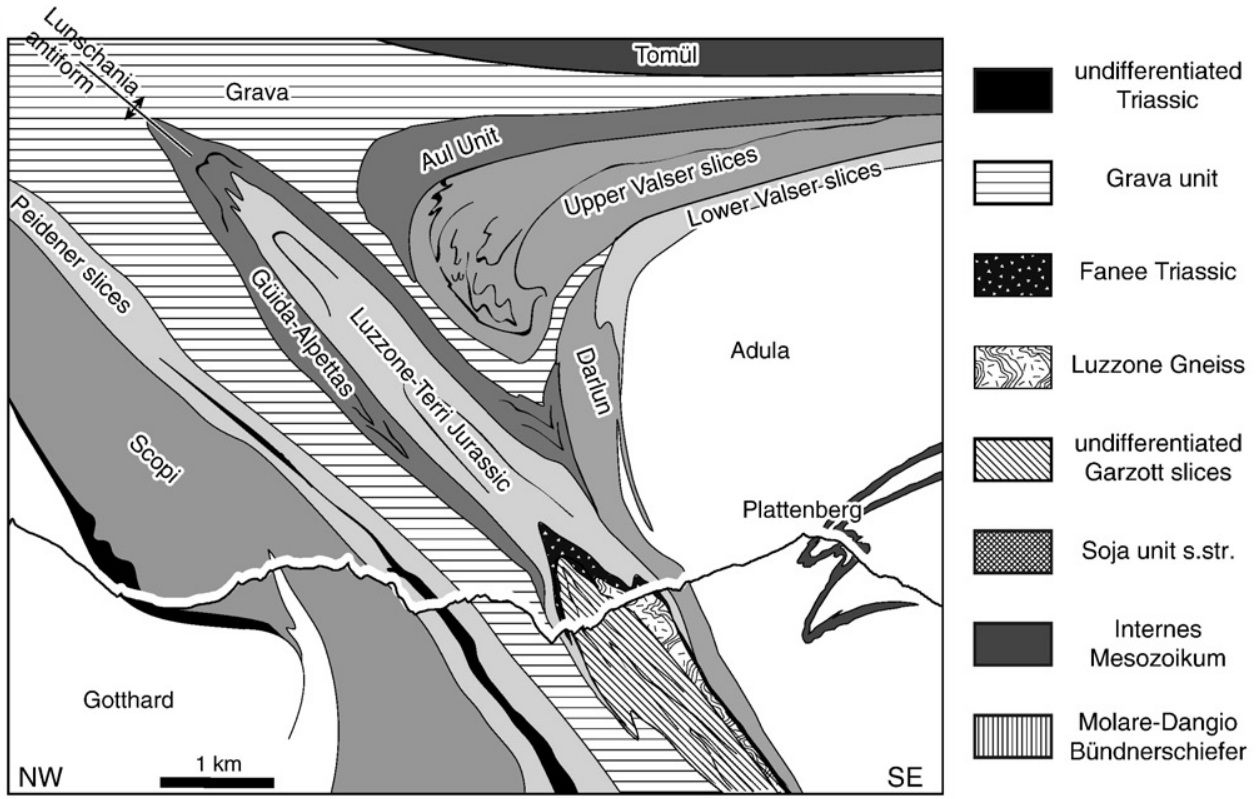

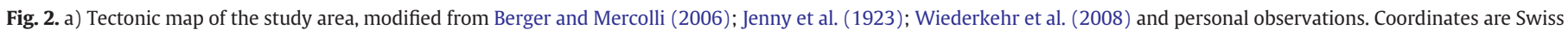
km grid b) Simplified tectonic profile through the study area, trace of profile in Fig. 2a. 


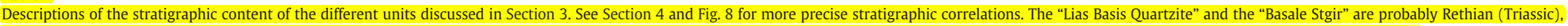
but since its lithological character is even Liassic (Infralias) they are classed in the "Younger than Triassic" row. We limit to the Triassic row only the typical Triassic lithologies (e.g. Melser, Roti, Quartenschiefer).

\begin{tabular}{|c|c|c|c|c|c|c|}
\hline & \multicolumn{2}{|c|}{ Simano nappe } & \multirow{2}{*}{$\begin{array}{c}\text { Soja unit } \\
\text { Soja unit s.str. }\end{array}$} & \multicolumn{3}{|c|}{ Adula nappe } \\
\hline & Lower limb & Upper limb & & Plattenberg (fig. 3b) & Hennasädel (fig. 3c) & Hohbüel \\
\hline . & Unknown & Unknown & Unknown & $\begin{array}{l}\text { - Plattenberg Formation: } \\
\text { dolomitic breccia with } \\
\text { quartzitic to dolarenitic } \\
\text { matrix. } \\
\text { The Breccia contains sidero- } \\
\text { lithic pebbles and presents } \\
\text { several dolarenitic to } \\
\text { calcarenitic intercalations. } \\
\text { One of this intercalations is } \\
\text { studded with crinoidal plates. } \\
\text { The uppermost part o } \\
\text { breccias contains sonn } \\
\text { intercalations of pure } \\
\text { limestone bed. } \\
\text { - Coarse--grained micaceous } \\
\text { quartzite, only locally } \\
\text { present. }\end{array}$ & $\begin{array}{l}\text { - Alternating series of } \\
\text { calcschists and impure } \\
\text { marbles. } \\
\text { - Pure marble }(>10 \mathrm{~m}) \text {, the } \\
\text { fresh rock is banded, } \\
\text { especially at the basis ( } \mathrm{cm} \\
\text { alternation of white and } \\
\text { light-blue marble). } \\
\text { - Sandy marble, the marble } \\
\text { lost rapidly }(<50 \mathrm{~cm}) \text { all the } \\
\text { impurities upsection. } \\
\text { - Metasandstone }(<1 \mathrm{~m}) \text {, it is } \\
\text { mainly composed of quartz- } \\
\text { feldspar and minor amount } \\
\text { of micas, brown calcite and } \\
\text { dolomite. }\end{array}$ & Unknown \\
\hline 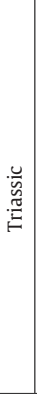 & $\begin{array}{l}\text { - Tabular and yellow } \\
\text { dusty dolomite with } \\
\text { intercalations of a } \\
\text { granular dolomite } \\
\text { (Zellen Dolomite) } \\
\text { - Coarse-grained } \\
\text { arkose with few } \\
\text { intercalations of a } \\
\text { grey quartzite. The } \\
\text { arkose is richer in } \\
\text { dolomite and calcite } \\
\text { upsection. }\end{array}$ & $\begin{array}{l}\text { - "Dolomie bicolori". } \\
\text { - Grey and massif } \\
\text { quartzite. }\end{array}$ & $\begin{array}{l}\text { - The series is cut by the thrust of the } \\
\text { Molare-Dangio Bündnerschiefer } \\
\text { (Section 2, fig } 1 \text { and } 2 \text { ). } \\
\text { - Sugary white massif dolomite, whose } \\
\text { bright and massif aspect } \\
\text { vanishes upwards. } \\
\text { "Dolomie bicolori". } \\
\text { - Dark yellow dolomite (5-8m), impure } \\
\text { at its base. } \\
\text { - Alternation ( } 1 \mathrm{~m} \text { ) of quartzite, impure } \\
\text { marble, calcareous micaschists and } \\
\text { impure dolomite. } \\
\text { - Grey and massif quartzite, it } \\
\text { becomes rich in micas upsection. }\end{array}$ & $\begin{array}{l}\text { - "Dolomie bicolori". } \\
\text { - Dark yellow dolomite. } \\
\text { - Carbonate-rich micaschists. } \\
\text { - Thin white grey quartzite, in } \\
\text { sharp contact with the } \\
\text { basement. }\end{array}$ & $\begin{array}{l}\text { - "dolomie bicolori". } \\
\text { - Pale yellow or off-white } \\
\text { dolomite. } \\
\text { - Carbonate-rich micaschists } \\
\text { with few thin intercalations } \\
\text { of a sandy and micaceous } \\
\text { dolomite. } \\
\text { - Grey quartzite, partly } \\
\text { conglomeratic at its basis. } \\
\text { It becomes rich in } \\
\text { impurities upsection. }\end{array}$ & $\begin{array}{l}\text { - "Dolomie bicolori". It } \\
\text { starts with a first dark-grey } \\
\text { bed. } \\
\text { - Homogeneous dark-yellow } \\
\text { dolomite }(2 \mathrm{~m}) \text {. } \\
\text { - Marble }(1 \mathrm{~m}) \text {, it can be } \\
\text { white or blue and it is } \\
\text { intimately intercalated with } \\
\text { several centimetric } \\
\text { dolomitic beds. } \\
\text { - Quartzitic and calcareous } \\
\text { micaschists }(<1 \mathrm{~m}) \text {. } \\
\text { - Grey quartzite }(<1 \mathrm{~m}) \text {, in } \\
\text { sharp contact (reversed) } \\
\text { with the basement. }\end{array}$ \\
\hline 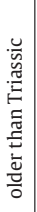 & \multicolumn{2}{|c|}{ - Old polycyclic para- and orthogneiss. } & $\begin{array}{l}\text { - Arkosic sandstones, few conglome- } \\
\text { ratic intercalations (the so-called } \\
\text { Soja Verrucano) are present } \\
\text { between the arkosic sandstones and } \\
\text { the overlying quartzite. } \\
\text { - Old polycyclic gneiss, locally with } \\
\text { lenses of amphibolites. }\end{array}$ & $\begin{array}{l}\text { - Garenstock Augengneiss } \\
\text { with eclogitic boudins } \\
\text { (Cavargna-Sani et al.., } \\
\text { 2010a; Jenny et al., 1923). }\end{array}$ & $\begin{array}{l}\text { - Heterogeneous } \\
\text { pre-variscan basement. }\end{array}$ & - old paragneiss. \\
\hline
\end{tabular}




\begin{tabular}{|c|c|c|c|c|c|c|}
\hline \multirow{3}{*}{ 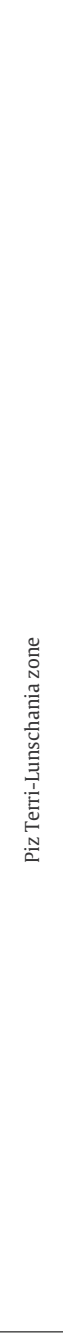 } & & 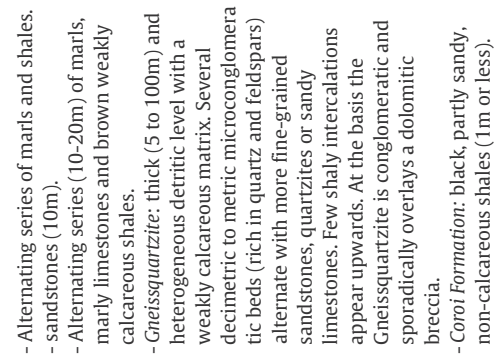 & 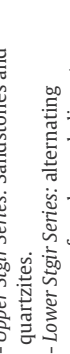 & 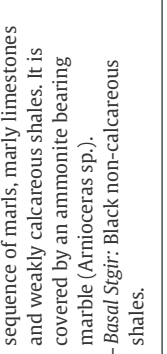 & 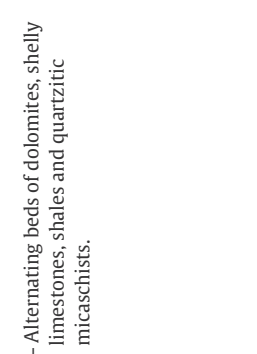 & $\begin{array}{l}\text { J् } \\
\text { D } \\
\text { E } \\
5\end{array}$ \\
\hline & & 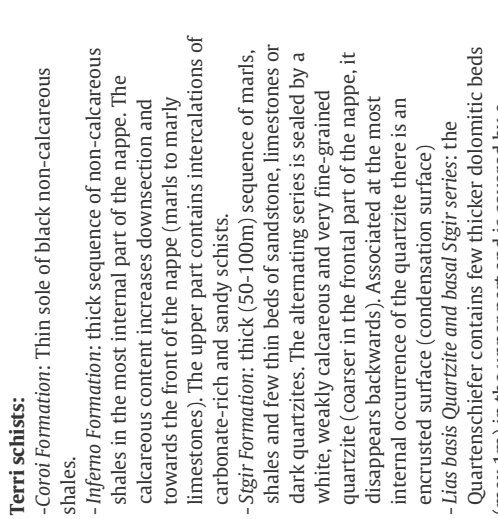 & 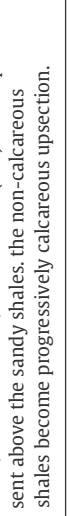 & 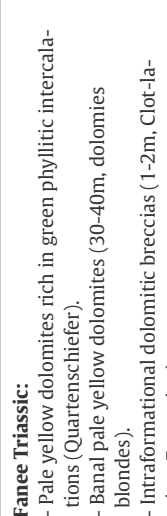 & 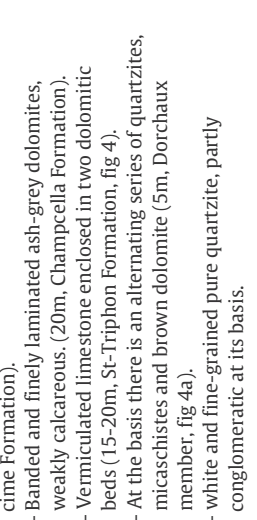 & 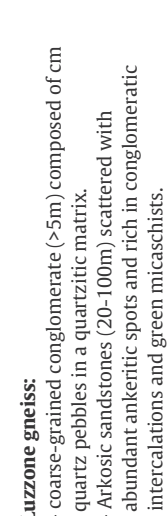 \\
\hline & 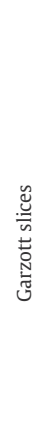 & 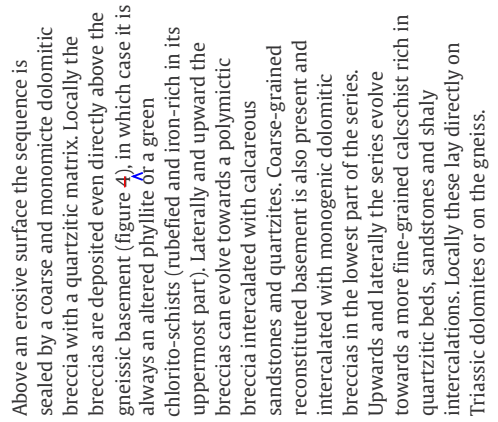 & & 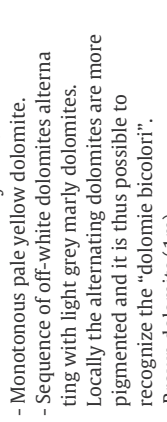 & 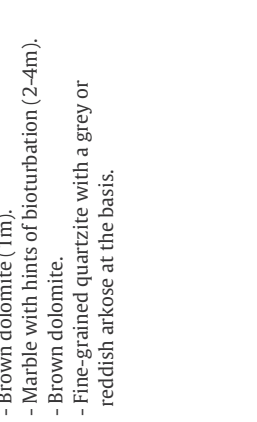 & 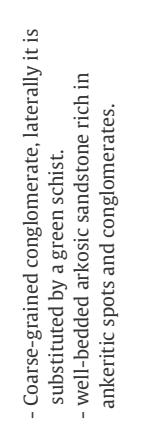 \\
\hline 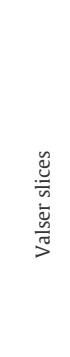 & 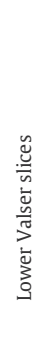 & $\begin{array}{l}\text { 䓂 } \\
\text { 站 }\end{array}$ & & 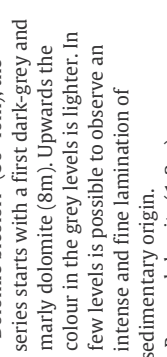 & 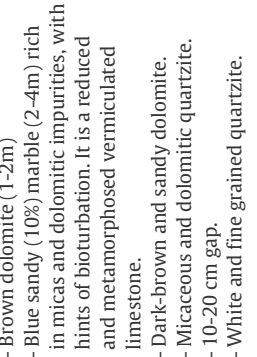 & \\
\hline & & 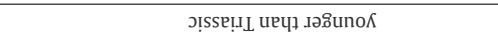 & & & sse!! & 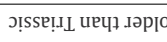 \\
\hline
\end{tabular}


mainly made of Paleozoic or older gneissic basement with remnants of sedimentary cover (Preiswerk et al., 1934). The contrasted tectonic syntheses of Maxelon and Mancktelow (2005) and of Steck (2008) give a measure of the uncertainties that still characterise our present-day understanding of its tectonic structure. During Alpine collision the Lepontine dome suffered severe metamorphic conditions increasing from upper greenschist facies in the north to upper amphibolite in the south (e.g. Fox, 1975; Frey, 1969, 1978; Niggli, 1970; Trommsdorff, 1966; Wenk, 1970). This barrowian metamorphism is preceded by a subduction related high-pressure event, ranging from blueschist to eclogite conditions (e.g. Heinrich, 1982, 1986; Nagel, 2008; Wiederkehr et al., 2008). The metamorphic evolution of the metasediments in the northern part of the Lepontine dome has been recently reviewed and improved by Wiederkehr et al. (2008, 2009, 2011). Despite deep subduction and strong deformation the nappes usually still preserve more or less complete remnants of their original Mesozoic-Tertiary sedimentary cover (e.g. Bianconi, 1971; Matasci et al., 2011). Moreover between the main nappes it is possible to find thinner zones of allochtonous metasediments, detached from more internal homelands (e.g. Bianconi, 1971; Etter, 1987; Galster et al., 2010; Probst, 1980). The remnants of the former Jurassic distal European margin are now distributed among these different tectonic units, i.e.: the Gotthard massif, the Lucomagno-Leventina nappe, the Simano nappe, the Soja unit, the PizTerri Lunschania zone, the Adula nappe and the Misox zone (Fig. 1).

The Gotthard massif is the lowest tectonic element in the study area. It consists of Paleozoic and older gneisses covered by Permian "Verrucano" and Triassic dolomites (Baumer et al., 1961; Brunnschweiler, 1948; Fehr, 1956). The Jurassic to Tertiary cover has been detached and transported further north into the Helvetic nappes (Etter, 1987). The Gotthard massif is overthrusted by the Scopi and the Peidener zones (the so-called "Gotthard Massivischer Mesozoikum" GMM; Spicher, 1980) consisting of Mesozoic sediments of Triassic and Jurassic age. The Scopi zone lays partly overturned but its stratigraphic content is coherent and perfectly recognizable. It is of Helvetic type: above a thin Triassic, three thicker subdivisions of Jurassic age are distinguished: the Stgir, the Inferno and the Coroi Formations (Baumer, 1964; Baumer et al., 1961; Etter, 1987; Frey, 1967; Jung, 1963). The Stgir and the Inferno Formations have also been recognised in the imbricated Peidener zone (Baumer et al., 1961), where the stratigraphic record is slightly different but still of Helvetic type. These series provide an important tool of correlation and are a precious link between the classical Helvetic Liassic of the Glarus nappe (further north; Trümpy, 1949) and the Liassic cover of several Penninic units (e.g. Galster et al., 2010). We briefly summarize them here:

1) The Stgir Formation: above a quartzite layer ("Lias Basis Quarzite"), it is composed by the Basal Stgir (shales), the Lower Stgir (marls, marly limestones and shales) and the Upper Stgir series (richer in sandstones and quartzites).

2) The Inferno Formation: rich in belemnites, it is divided into a Lower (alternation of marls and marly limestones), a Middle (marls) and an Upper series (marls and marly limestones). The second half of the Formation is richer in detrital content. Locally the homogeneity of the Formation prevents the distinction of the three subdivisions.

3) The Coroi Formation is a homogeneous thick series of black noncalcareous shales.

The Lucomagno-Leventina nappe is the next higher gneissic-body. Its thin Triassic cover, formed of arkosic sandstones and dolomites, is of Helvetic type (Ammann, 1973; Baumer, 1964).

The Molare synform (Ammann, 1973) separates the Lucomagno nappe from the overlaying Simano nappe, a thick and complex recumbent gneissic-body that preserves a sole of Triassic cover. The sediments of the upper normal limb of this nappe form the lower limb of the North Claro syncline (Figs. 1 and 2a), a structure interpreted as a nappe separator between the Simano and the overlaying Adula nappe (Maxelon and Mancktelow, 2005).

Apparently in the core of the Claro syncline, there is the thinner Soja unit, whose precise tectonic position is still an open question (Argand, 1918; Egli, 1966; Galster et al., 2010; Jenny et al., 1923). The unit is enclosed tectonically into allochtonous metasediments (Molare-Dangio Bündnerschiefer after Probst, 1980).

The Adula nappe is a large tectonic unit that overlies the Simano and Soja units. Its internal structure is extremely complicated (e.g. Berger et al., 2007; Jenny et al., 1923; Löw, 1987; Nagel, 2008). It mainly consists of a basement made of Paleozoic and older para- and orthogneisses with associated metabasites and a few ultramafic lenses, assembled during the Variscan (and older?) orogen and intruded by late Variscan granitoids, such as the Zervreila orthogneiss ( $293 \mathrm{Ma}$; Cavargna-Sani et al., 2010a). Near the front of the nappe (Fig. 2) the basement is at several places coated by a thin, highly deformed metasedimentary cover that also forms isoclinal folds of multi-kilometric amplitude penetrating deep into the basement (the so-called "Internes Mesozoikum" of the classical literature; Jenny et al., 1923; Löw, 1987). The lithological heterogeneity, the presence of intercalated Mesozoic bands and the relatively frequent existence of eclogite boudins (of both Alpine and Variscan age; Liati et al., 2009; Herwartz et al., 2011) suggested to some authors that the Adula nappe was a lithospheric mélange rather than a coherent unit (e.g. Engi et al., 2001; Trommsdorff, 1990).

Above the Adula nappe and below the Middle Penninic (and Briançonnais) Tambo nappe, there is the Misox zone (Gansser, 1937), characterised by thick sequences of mostly Cretaceous calcschists (the so-called Bündnerschiefer) with few basement slices and intercalated Jurassic MORB-type metamafics and rare serpentinites (Dürr et al., 1993; Gansser, 1937; Kupferschmid, 1977; Liati et al., 2005; Nabholz, 1945; Steinmann, 1994; Steinmann and Stille, 1999). The Misox zone consists of two nappes and three imbricated zones, respectively and from top to bottom these are: the Tomül and the Grava nappes (with their basal mélanges), the Aul unit, the Upper Valser and the Lower Valser slices ("Valser Schuppen") (Wyss and Isler, 2007).

To the north the Grava nappe is folded by the Lunschania antiform (a fold formed during a post-nappe folding phase) below the Adula nappe (Figs. $1 \mathrm{~b}$ and $2 \mathrm{~b}$ ). Between these two nappes and in the core of the Lunschania antiform there is the Piz Terri-Lunschania zone consistsing of imbricated slices of metasediments (Fig. 2). At the bottom of the zone, near the Luzzone lake, the gneissic substratum of the lowest slice is exposed. The gneiss, mainly derived from Verrucano, was classically considered as the northern continuation of the Soja unit (Egli, 1966; Jenny et al., 1923; Kupferschmid, 1977; Probst, 1980; Wiederkehr et al., 2008). Recently Galster et al. (2010), based on stratigraphic arguments, separated the Verrucano in the Piz Terri-Lunschania zone from the Soja nappe and proposed an UltraAdula origin (i.e. the homeland was located in a more internal position relative to the Adula) for the zone. Currently the Piz TerriLunschania zone is divided in 3 different groups of tectonic elements, from bottom to top: the Luzzone-Terri nappe, the Darlun zone and the Güida-Alpettas zone (Galster et al., 2010; Kupferschmid, 1977; Probst, 1980). In this contribution we will add a fourth group of tectonic elements that is located at the bottom of the zone: the Garzott slices (Fig. 2, see Section 3.5.2).

\section{Stratigraphic data}

We present 10 synthetic stratigraphic sections from 7 units located in the Lower Penninic of the Central Alps (Table 1). Some of these sections have already been presented in the literature, but new structural observations permit to reinterpret their stratigraphic content and to integrate it in the frame of modern Alpine Stratigraphy. Other sections have recently been investigated and are presented here for the first time. 
We introduce a new group of Triassic facies that we name "dolomie bicolori". This group consists of a characteristic alternation of $\mathrm{cm}$ to metric yellow and grey dolomitic beds. The colour of the yellow beds is a pale pastel yellow or locally a more accentuated lemon yellow. The grey in itself is an ash grey, sometimes darker with a drift towards a grey-violet tint. Careful observations in the "dolomie bicolori" reveal that the chromatic alternation is partly enhanced by folding, but it is also an original sedimentary feature. A first dark-grey, locally marly, dolomitic bed marks the beginning of the bichromatic alternation.

The "dolomie bicolori" are also exposed in the Campo Lungo area (Western Simano nappe), where they are described in detail by Bianconi (1971).

\subsection{The Simano nappe}

Two different groups of facies characterise the sedimentary cover of the Simano nappe: one is observed along the upper and normal flank in the SE of Val Soi (lower limb of the Claro syncline, Figs. 1 and 2), the other outcrops especially around the front in the NW of Val Soi and in the lower limb of the Eastern Simano. The most striking difference is the presence (respectively absence) of the "dolomie bicolori" in one limb (upper) compared to the other (lower).

\subsection{Soja unit s.str}

The stratigraphic column described for the Soja unit s.str. can be extended to the entire pile of sediments that separates it from the overlaying Adula nappe.

The unit is complexly folded and shows a core of old polycyclic gneiss. Cover sediments are best developed in the upper part of the unit, above the polycyclic basement, but the presence of arkosic sandstones and conglomerates (the so-called Soja Verrucano) on both sides of the polycyclic gneiss suggests the existence of an anticline folding the Soja unit.

The "dolomie bicolori" characterise the Triassic cover (Fig. 3a).

\subsection{Adula nappe}

Among the several occurrences of the Mesozoic cover of the Adula, we describe the most significant and best-exposed outcrops. These are: 1) the area around the Plattenberg summit (3041 m). The area is characterised by complex folding (Egli, 1966; Jenny et al., 1923; Löw, 1987), but thanks to the high altitude the outcrops are of excellent quality (Fig. 3b). A detailed stratigraphic description of this area is given in Cavargna-Sani et al. (2010b). 2) the Hennasädel cliff $(2466 \mathrm{~m})$, where the stratigraphic column is complexly folded (Zulbati, 2008) but still recognizable (e.g. Van der Plas, 1959). 3) the Hohbüel hill (2426 m), where the stratigraphic section lies in an overturned position below the flat hill. See Fig. 2a for outcrops locations.

Noteworthy are the stratigraphic nature of the contact between basement and cover and the presence of the "dolomie bicolori" in the three sections. At the Plattenberg and at the Hennasädel, where the stratigraphic column is more complete, there are several lines of evidences suggesting important sedimentary gap and the presence of syn-sedimentary faults.

\subsection{Valser slices}

The stratigraphic content of the Lower Valser slice differs from that of the Upper Slice. Triassic lithologies and well-known marker horizons are missing in the Upper Valser slice, thus we focus especially on the Lower Valser slice, where the "dolomie bicolori" are well developed. Table 1 reports the uppermost Triassic occurrence in the Lower Valser slice, directly below the thrust of the Upper slice (Wissflue cliff, $1 \mathrm{~km}$ SE of Vals).

\subsection{The Piz Terri-Lunschania zone and its tectonic substratum}

\subsubsection{The Luzzone-Terri nappe}

The stratigraphy of the Luzzone-Terri nappe has recently been discussed by Galster et al. (2010). These authors highlighted the Briançonnais affinity of the gneissic "basement" (Luzzone gneiss) and the Triassic cover (Fanee Triassic, Fig. 4). On the other hand the Liassic cover, in stratigraphic contact (Fig. 5) with the Briançonnais Triassic, is of clear Helvetic affinity.

The arkosic sandstones in the Luzzone gneiss display clear analogies with the Moosalp Formation (Permian) in the external part of the Briançonnais paleogeographic domain (Genier et al., 2008; Thélin, 1982). The overlying conglomerate with its quartz pebbles is similar to the Embd Member (upper Permian) of the external Briançonnais (Genier et al., 2008) or more generally to the Verrucano Briançonnais (Trümpy, 1966). The Fanee Triassic displays definite analogies with the Triassic Formations that characterise alpine units classically assigned to the Briançonnais paleogeographic domain elsewhere in the Alps (StTriphon, Champcella and Clot-la-Cime Formations).

In the Liassic cover we recognise the Helvetic Stgir, Inferno and Coroi Formations that characterise the so-called Gotthard-MassivisherMesozoikum in the Lukmanier-Pass area (Baumer et al., 1961) or the cover of the Gotthard massif near the Nufenen-Pass further to the west (Liskay, 1965).

\subsubsection{The Garzott slices}

Detailed fieldwork and mapping in the core of the Lunschania antiform around the Luzzone lake reveal the existence of several tectonic objects below the thrust plane of the Luzzone-Terri nappe (Figs. 2 and 11). These objects, that we call Garzott slices, are the best candidates to represent the original tectonic substratum of the Luzzone-Terri nappe. The stratigraphic content of these slices is fundamental to link the Luzzone-Terri nappe, together with its Briançonnais content, to the Helvetic margin.

Our mapping suggests that the Verrucano of the Luzzone-Terri nappe, that on its back transport the whole Piz Terri-Lunschania zone, is only partly folded by the Lunschania antiform and does not constitute its core at all (Fig. 2b).

Moreover the Verrucano body of the Luzzone-Terri nappe (the former Northern Soja nappe, Galster et al., 2010) which was considered by previous workers as folded in a tight anticline does not show any reversed flank and is simply thrusted above several slices of gneiss and dolomites that have previously been erroneously attributed to its original inverse limb (compare our Fig. 2 with Fig. 25 in Probst (1980) and Fig. 3 in Wiederkehr et al. (2008)). Only the originally more advanced part of the nappe developed an inversed limb by fold ramps and has been subsequently refolded by the Lunschania antiform.

An independent confirmation to our new interpretation arises from the stratigraphy, which is different from that established in the Luzzone-Terri nappe (absence of the Embd member as well as the Champcella and Clot-la-Cime Formations, which are replaced by an analogue of the "dolomie bicolori").

The small river east of "Alp Garzott" is filled with blocks of breccias and conglomerates fallen down from the Garzott slices exposed in the cliff south of the river. Some megaclasts embedded in a pelitic or sandy matrix show a strong hydraulic fracturation or even a cataclastic fabric, features not observed in the surrounding matrix (perfectly preserved). Fracturation, comminution and fluids precipitation occurred prior to the incorporation of the block into the matrix. Moreover in the uppermost part of the Triassic series (which is cut by an erosion surface) it is possible to observe a deformed tectonic breccia preserving former "jigsaw puzzle" structures (Tarasewicz et al., 2005), these are not observed in the overlying sediments.

These observations strongly suggest the presence of a paleofault that controlled the sedimentation in the Garzott slices. 

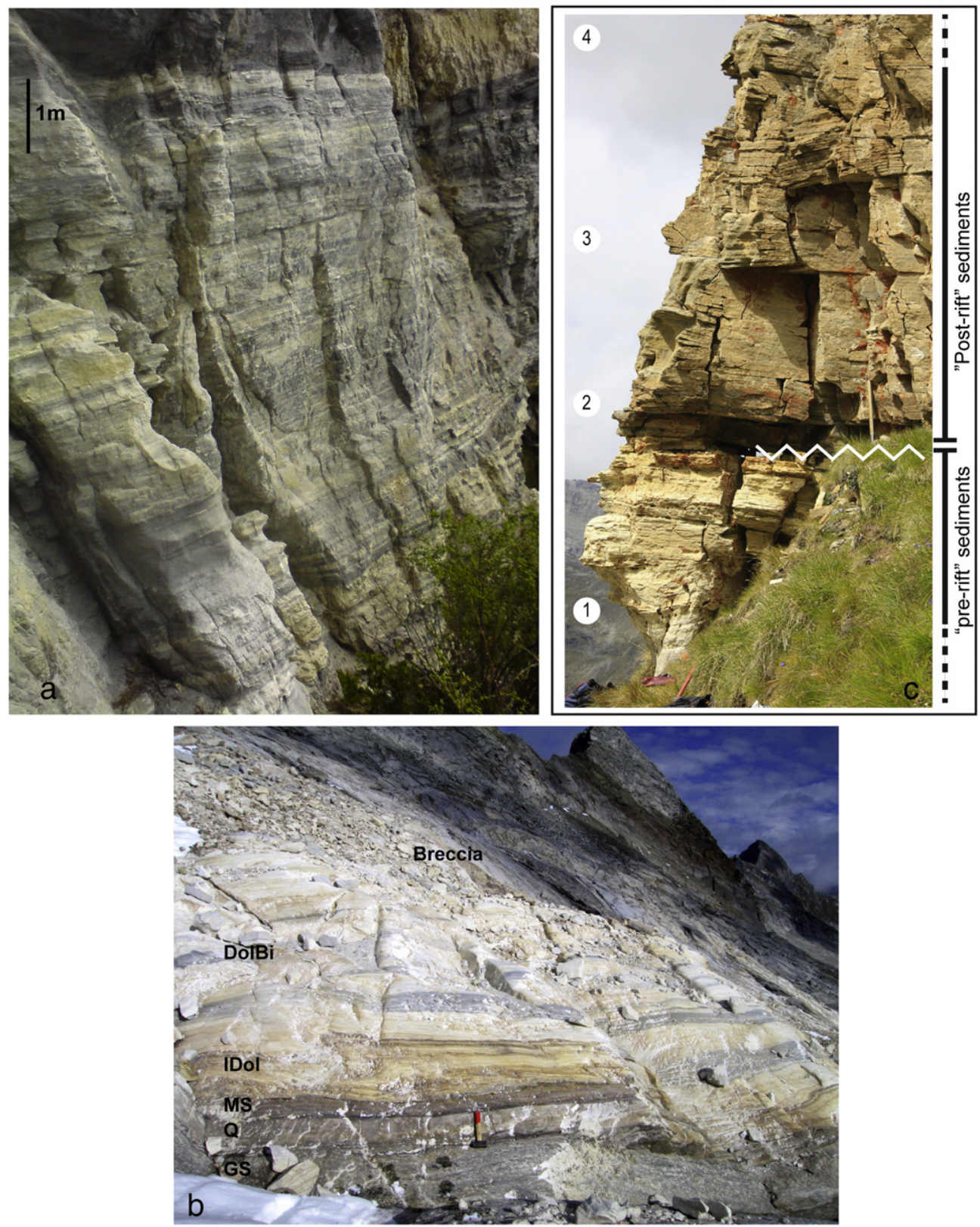

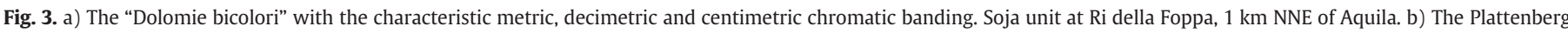

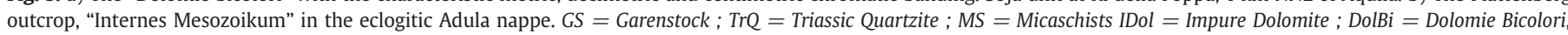

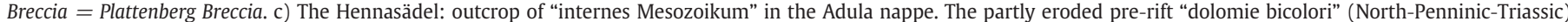

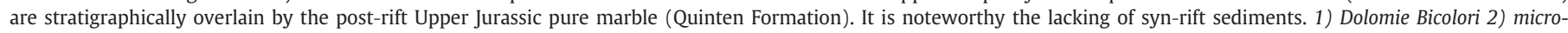

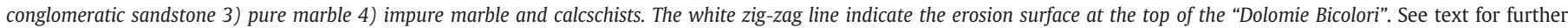
details.

\subsubsection{Güida-Alpettas zone}

The Güida-Alpettas zone is divided in two parts. These are the Alpettas zone in the upper limb of the Lunschania antiform and the Güida zone in the lower limb. The two zones are interpreted to merge in only one zone at the hinge of the fold (Kupferschmid, 1977; Probst, 1980).

The Güida zone is characterised by two metric to hectometric quartzitic beds, the so-called Gneissquarzite (Kupferschmid, 1977; Probst;, 1980; Uhr, unpublished; Wyss and Isler, 2007). The thickness of the two beds decreases more or less simultaneously towards the SW and both disappear before reaching the Luzzone lake. Our observations reveal that their disappearance is a consequence of folding: the two quartzitic beds are the same stratigraphic level folded around a tight synform which folds the whole Güida zone and ends near the banks of the Luzzone lake. The fold is an anticline reversed by the Lunschania antiform (Fig. 7).

If looked under this perspective, the stratigraphic content of the Güida zone is straightforward; above a remnant of Triassic rocks it is possible to recognise the Stgir (with its Sinemurian ammonites occurring in a limestone bed at the top of the Formation), the inferno and the Coroi Formations.

The described sequence is folded in-between the Gneissquarzite (see above). The contact between the detrital formations and the underlying shales (Coroi Formation) is always sharp (in the original upper limb of the "Güida anticline" the basis of the Gneissquarzite can be erosive below the Coroi Formation). In contrast the upper part of the Gneissquarzite passes in a transitional way into an alternating series of marls and marly limestones. 


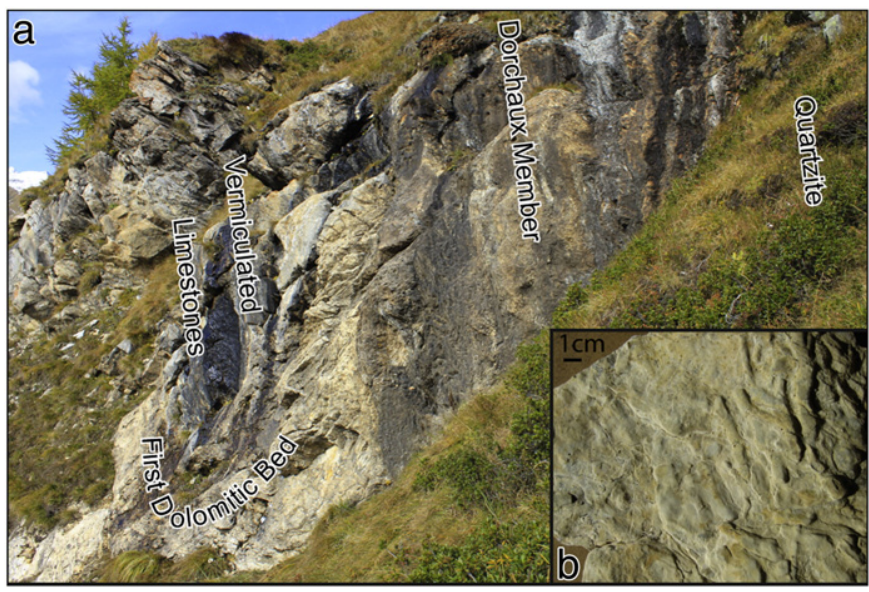

Fig. 4. a) The Dorchaux member at the Basis of the St-Triphon Formation (Fanee Triassic, Luzzone-Terri nappe) folded in a syncline. Further to the $\mathrm{NW}_{\Lambda}$ at the opening of the fold it is possible to observe a second dolomitic bed, the Champcella and the Clot-laCime Formations. b) exemple of a Vermiculated limestone from the Fanee Triassic in the Luzzone-Terri nappe. Modified after Galster et al. (2010).

On the other side of the Lunschania antiform, in the more internal Alpettas zone the stratigraphic content is similar (Kupferschmid, 1977; Probst, 1980), but a reef limestone (Geyer, 1977) replaces the Ammonite bearing limestone and in general all the facies suggest shallower conditions. The Gneissquarzite can be erosive even below the Inferno Formation and it is in general coarser (quartz grains up to $5 \mathrm{~mm}$ ).

\section{Stratigraphic correlations}

For the stratigraphic correlation only few paleontological data are available. However some correlations can be proposed based on a highly variable vertical record, several marker beds and the possibility to compare our sections with similar well-dated stratigraphic sections located elsewhere in the Alps. Therefore we are able to trace some lines of correlation among the different sections (Fig. 8).

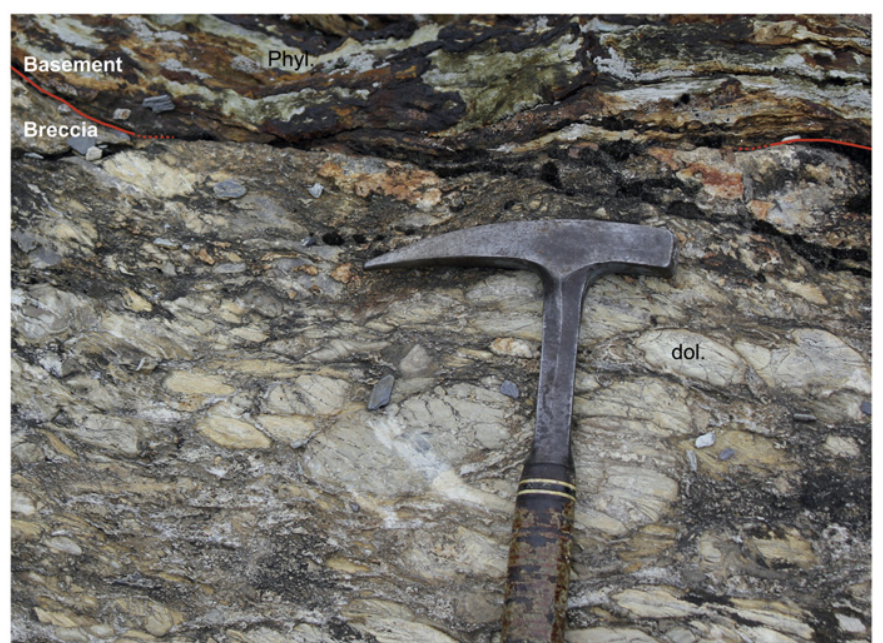

Fig. 6. A detail of the contact between the altered iron-rich Garzott gneiss and the fresh Garzott breccias. Dol = dolomite; Phyl $=$ Phyllite.

The restoration of the different units to their original relative positions in the Mesozoic is a combination of both stratigraphic and structural criteria. With the exception of the Piz Terri-Lunschania zone and the Soja unit positions it does not differ substantially from already published restorations (e.g. Probst, 1980; Schmid et al., 1996; Wiederkehr et al., 2008, 2009).

\subsection{Permian and Lower Triassic}

The "eotriassic quartzites" are the first well distributed marker bed. Some sections show a thick sedimentary formation already below this level. These sediments can be seen as a "Verrucano" and considered late Paleozoic to early Lower Triassic in age (Dössegger and Trümpy, 1972; Trümpy, 1966).

In the Briançonnais basin the quartzites are Lower Triassic. For the Helvetic realm, in the Mont Blanc area the arkoses are Lower to early

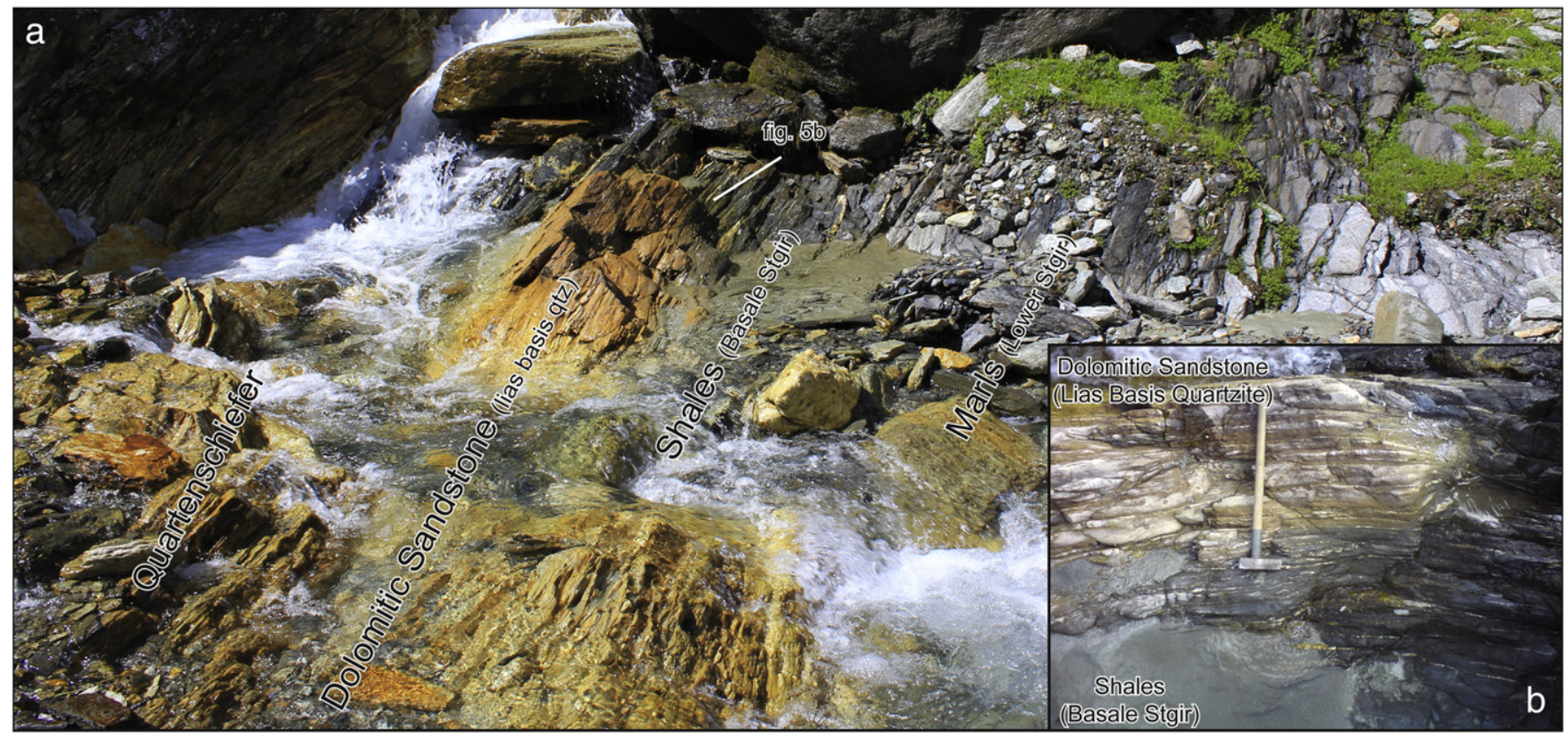

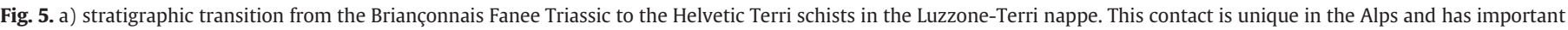

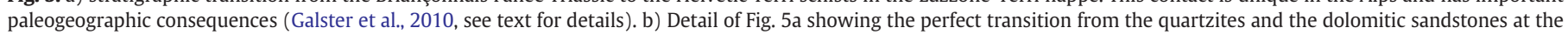
top of the yellowish Triassic lithologies to the shales at the basis of the black Liassic formations (see text for details). 


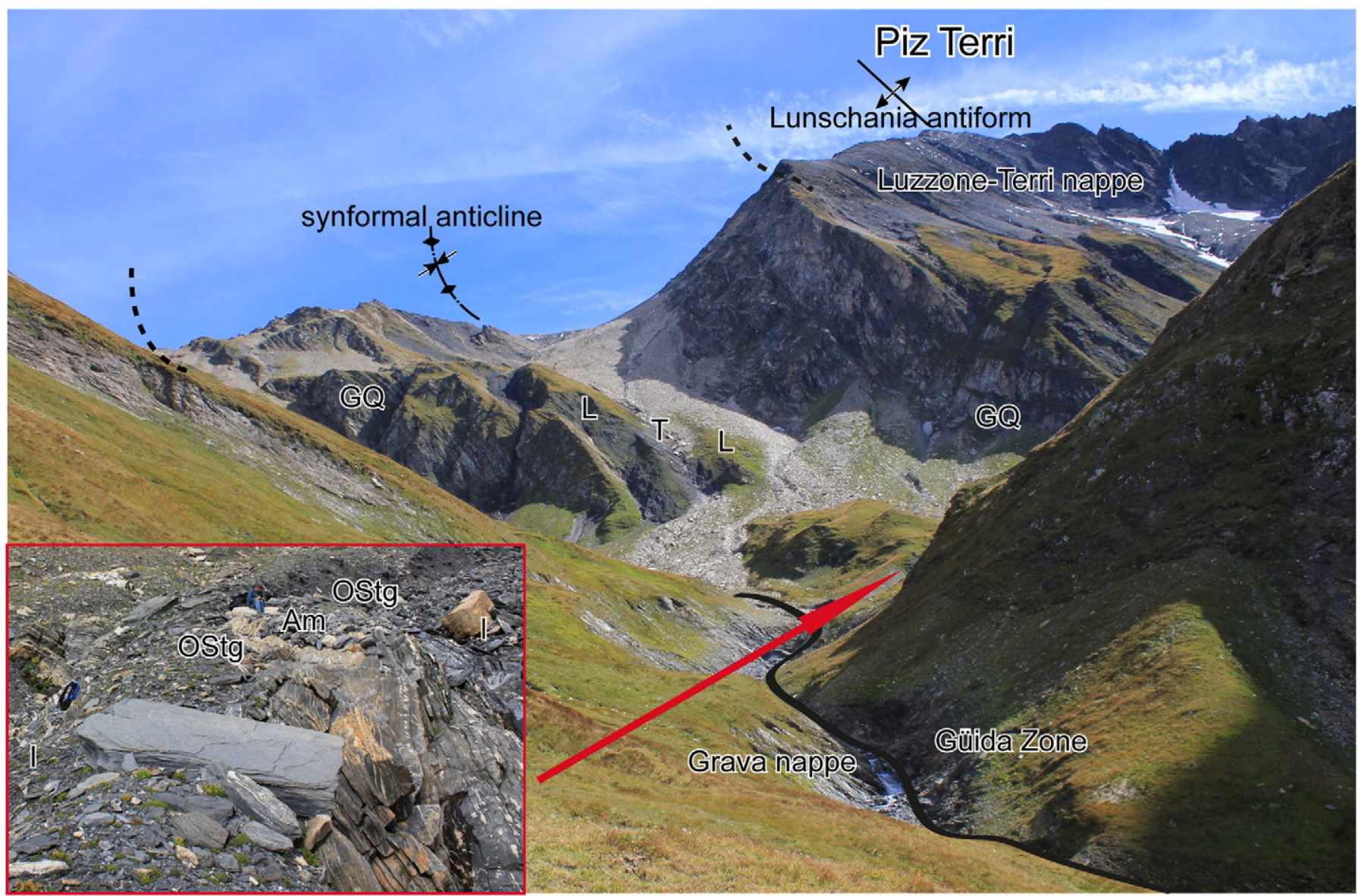

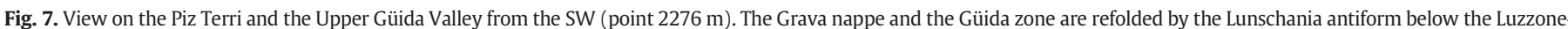

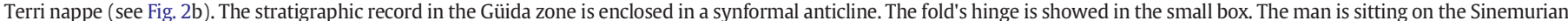

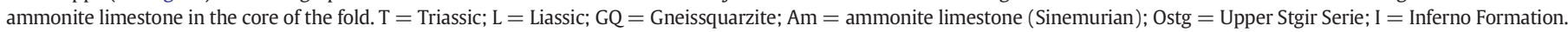

Middle Triassic (Avanzini and Cavin, 2009) and in the Aar massif they are Anisian (Gisler et al., 2007).

\subsection{Middle-Upper Triassic}

In some sections, there is a clear transition from silicoclastic to carbonate sedimentation, which spans from few centimetres to some metres testifying ephemeral conditions (Dorchaux Member, Fig. 4a) prior to the definitive drift towards carbonate sedimentation.

The progress of the carbonate front can be followed from the Luzzone-Terri nappe, where the Dorchaux Member spans $5 \mathrm{~m}$, to the Adula nappe, where the same horizon is progressively reduced to a few centimetres (we interpret the carbonate-rich micaschists as a reduced Dorchaux Member). The Dorchaux Member in the Briançonnais basin is early Anisian (Baud, 1976, 1987).

The St-Triphon Formation is clearly present in the Luzzone-Terri nappe but it can be followed only in the Garzott slices till the Valser slices, then it is progressively reduced, first to few limestone beds almost intercalated into a more dolomitic formation and finally to dark yellow or brown dolomitic beds located directly above the calcareous micaschists (Dorchaux Member). The St-Triphon Formation is completely absent in the Simano and Lucomagno nappes.

The St-Triphon Formation in the Middle Penninic is dated as Lower to Middle Anisian (Baud, 1976, 1987).

The Champcella Formation, present in an already reduced form in the Luzzone-Terri nappe is only a far kin of the "dolomie bicolori" of the Garzott slices. Some of its characteristics can still be observed in the Lower Valser slices but then they vanish in the "dolomie bicolori" of the Adula nappe. The age of the Champcella Formation is Upper
Anisian to Lower Ladinian (Mégard-Galli \& Baud, 1977), we extend this age to the "dolomie bicolori". This extrapolation seems to be confirmed by Ladinian crinoids in the Campolungo "bicolored dolomites" of the Western Simano nappe (Bianconi, 1965 pag. 574).

The Clot-la-Cime Formation has been recognised only in the Luzzone Terri-nappe, In the Middle Penninic its age spans from the Upper Ladinian to Carnian (Baud \& Mégard -Galli, 1975; Mégard -Galli, 1972). After the Carnian crisis the stratigraphic differences between the Briançonnais basin (especially its external part) and the Helvetic one are attenuated. The thick Briançonnais "dolomies blondes" cannot be distinguished from the Helvetic dolomitic formation in the absence of the Middle Triassic part of the sequence, especially in metamorphic terranes.

The arkoses at the base of the external Simano Triassic are partly dolomitic, especially in their upper part and they are directly followed by a thick pale yellow dolomitic formation.

Considered the massif encroachement of the "dolomies blondes" (mor or less the Briançonnais equivalent of the "Haupt Dolomit", Norian) we suggest that most of the dolomitic deposition in the external Simano and northward is a direct consequence of this phenomenon.

A confirmation to this scenario is suggested by a few thin and extremely rare ash-grey marly dolomites (already reported by Ammann, 1973) intercalated at the basis of the Lucomagno dolomitic sequence (the most external occurrences of an extremely reduced dolomia bicolore).

\subsection{Rethian}

The close association of quartzite, sandstones, dolomites, shellylimestones, micaschists and black, non calcareous, shales is typical 


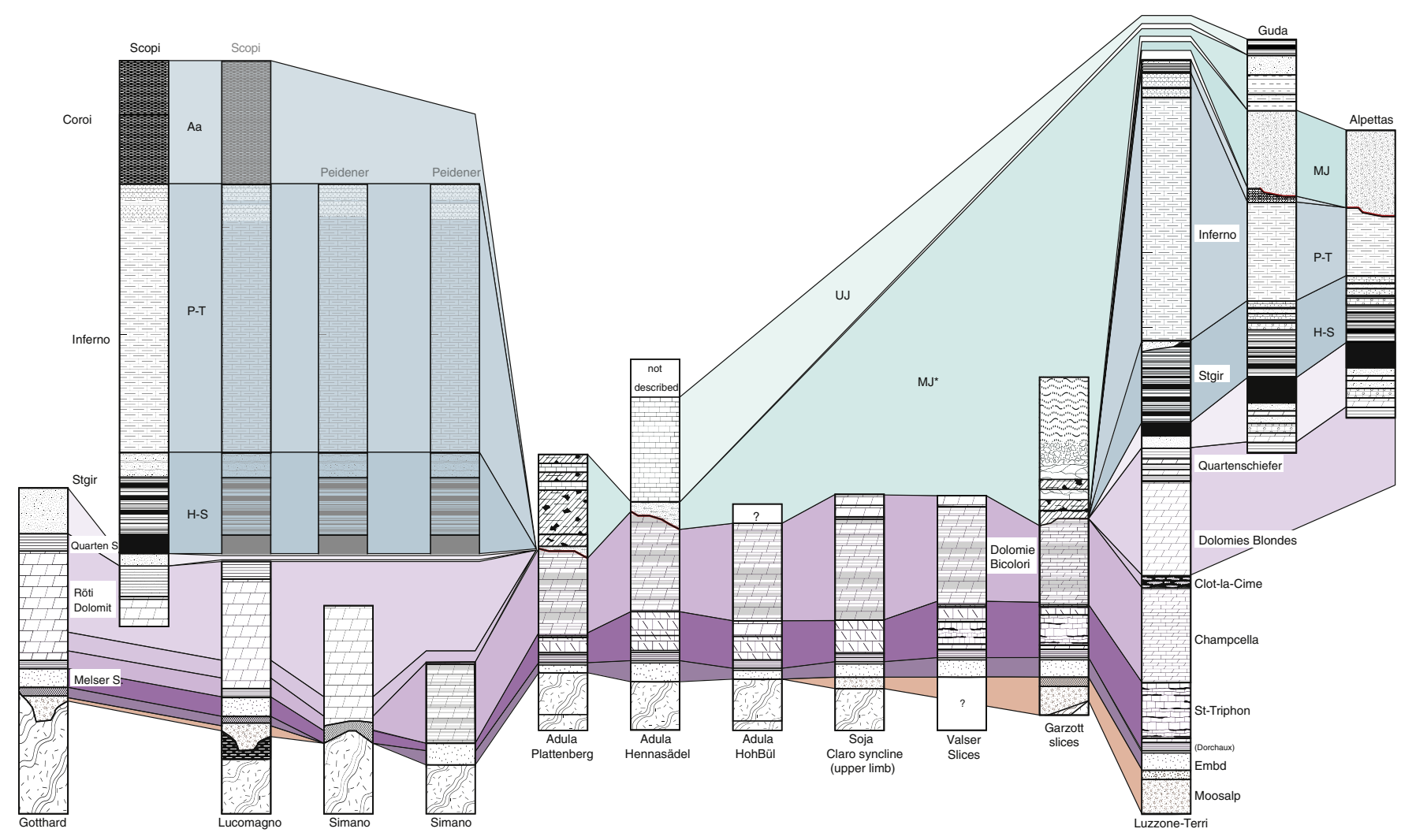

NORTH-PENNINIC-TRIASSIC
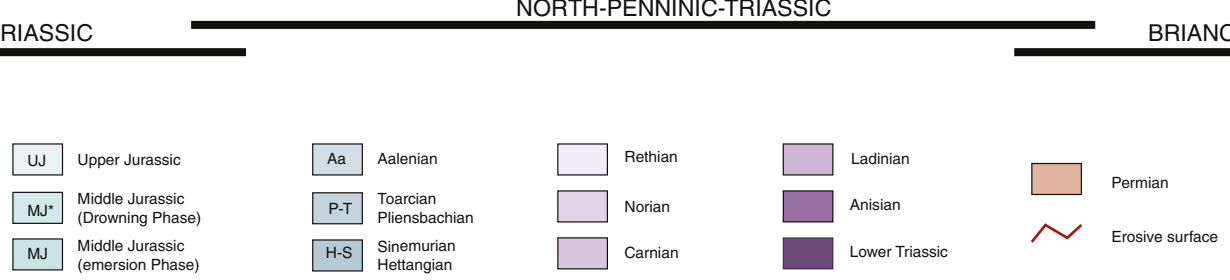

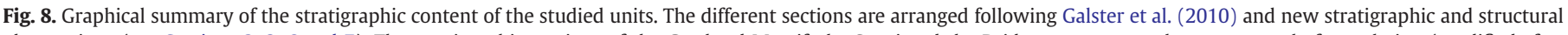

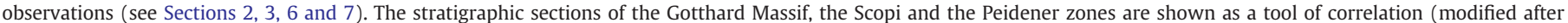

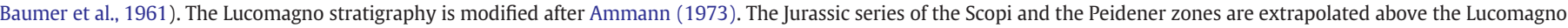

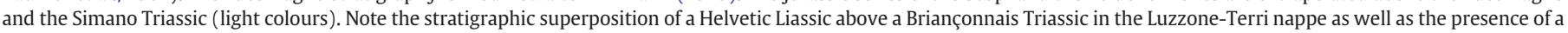

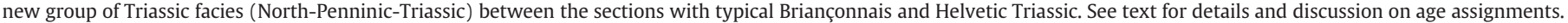

for the "Infralias" of the ancient authors, dated as Rethian-early Hettangian in the Glarus Alps (Trümpy, 1949).

\subsection{Hettangian-Sinemurian}

The attribution to the Hettangian and Sinemurian is based on the recognition of the Stgir Formation, which is dated by Gryphea arcuata and Arnioceras sp. directly below and inside the detrital input (Upper Stgir series) (Baumer, 1964; Jung, 1963). The Stgir Formation in the Güida zone, can be dated directly by the Sinemurian Arnioceras $s p$. found by A. Uhr (Unpublished, courtesy of A. Isler). The reef limestone in the Alpettas zone is dated as Sinemurian (Geyer, 1977; Kupferschmid, 1977; Uhr, unpublished). The paleontological findings allow a good correlation with the most typical Helvetic sections where similar facies are present. A good marker is the Lotharingian (Upper Sinemurian) detrital input (e.g. Loup, 1992).

\subsection{Pliensbachien-Toarcian}

The Inferno Formation is Post-Sinemurian and correlated with the Pliensbachian-Toarcian Sexmore series in the Glarus Alps (Baumer et al., 1961). In this regard a Pliensbachian age fit well with the presence of a second detrital input that can be correlated with the Domerian detrital event in the Helvetic basins (Loup, 1992).

\subsection{Aalenian}

The Aalenian Dugny Formation in the French Alps (Epard, 1990) finds a perfect equivalent in the Coroi shales. The same for the Aalenian in the Glarner Alps (Trümpy, 1949) as highlighted by Baumer et al. (1961). Locally in the basin the shaly non-calcareous formation starts already in Toarcian (Epard, 1990; Aubert de la Rue and Weidmann, 1966) and partly replaces the marly formation, it seems to be the same in the internal part of the Luzzone-Terri nappe (Table 1).

\subsection{Middle Jurassic}

The Gneissquarzite is deposited directly above the Coroi Formation of probable Aalenian age and its detrital content ( $q \mathrm{tz}+\mathrm{fds}$ ) suggests the presence of an emerged land subjected to erosion. Since the Inferno and the Coroi Formations in the Güida zone are only weakly detritic we assume that this land emerged during or after the early Middle Jurassic or that this period coincided with a major current reorganisation in the basin. 
The Plattenberg Formation and the breccias in the Garzott slices, include dolomitic and calcareous pebbles of different type, none of these displays a facies different from Triassic or Lower Jurassic rocks, thus they can be considered Lower Jurassic or younger with a great probability of a Middle Jurassic age (absence of pebbles from the Upper Jurassic limestone).

Moreover the Plattenberg Breccia reworks siderolithic pebbles, contains crinoids and follows a quartzitic microconglomerate above an eroded Triassic dolomite. From this we deduce that its formation is subsequent to an emersion phase and happened during a drowning phase.

The most suitable period for these formations is the Middle Jurassic, a period during which generalised emersion is observed in several domains (e.g. Badoux and Mercanton, 1962; Baud and Masson, 1975; Trümpy, 1945). The Gneissquarzite is considered as deposited during the emersion phase (Aalenian to Bathonian?), the Garzott slices, the Plattenberg breccias and the formations above the Gneissquarzite during the drowning phase (Bathonian to Oxfordian?).

\subsection{Upper Jurassic}

The thick and extremely pure marble at the Hennasädel recalls the Kimmeridgian-Thitonian marbles in the Quinten Formation (e.g. Anatra, 1986; Kugler, 1987). It is deposited above an eroded surface and lies directly above a sandstone bed locally microconglomeratic at its basis.

This situation is identical to the stratigraphy of the Antabia group, recently established in the Lower Penninic Antigorio nappe (Matasci et al., 2011). We therefore correlate the stratigraphy at the Hennasädel with the Antabia group for which an Upper Jurassic age has been proposed (Matasci et al., 2011).

The sandstones below the "Upper Jurassic" marble can be considered as late Middle Jurassic or even early Upper Jurassic (drowning phase, see above).

\section{The Stratigraphic signature in the local context}

Prior to discussing the integrated interpretation of the tectonostratigraphic record and its eventual contribution towards a better understanding of both pre-orogenic and orogenic history of the Central Alps we need to highlight some important aspect of some sections.

\subsection{The Garzott slices}

The discovery of the Garzott slices is important for the regional tectonics of the Piz Terri-Lunschania zone and adds important information even on the pre-orogenic significance of the zone.

The stratigraphic record around the Luzzone lake indicates the presence of paleo-faults.

In rifted margin the existence of high angle normal faults related to extension is known since the beginning of modern basins analysis (e.g. Vening Meinesz, 1950). More recently several studies highlighted the existence of low angle normal faults in distal rifted margin (e.g. Froitzheim and Eberli, 1990; Whitmarsh et al., 2001), these faults that act as detachments, are an efficient mechanism to thin the continental crust (Lavier \& Manatschal, 2006).

Masini et al. (2011) described in detail the evolution of the Samedan basin (Lower Austroalpine, Graubunden), which is convincingly interpreted as a supra-detachment basin. The signature for supradetachment basins as indicated by Masini et al. (loc cit.) corresponds with the tectonosedimentary record observed in the Garzott slices (Section 3.5.2). The analogies are: 1) the evolution from monomictic (dolomitic) breccias towards coarse-grained reconstituted basement and 2) the interbedding of these two deposits, testifying the simultaneous availability of two completely different sources (Hangingwall vs Footwall); 3 ) the upwards evolution to polymictic breccias and sandstones (reddish litharenites) reworking pre- and early syn-rift sediments (Triassic and Liassic) and 4) the sealing with a more fine-grained sequence of shales and more mature arkosic beds. The distal turbidites reported by Masini et al. (2011) in the Samedan Basin are not actually recognised in the Garzott slices.

In the light of these analogies we propose that the Garzott fault and the associated sediments testify the presence of a "supra-detachement" basin bordered by allochtones (the Garzott slices and maybe even the biggest Luzzone-Terri nappe).

The Ultra-Adula origin of the Piz Terri-Lunschania zone (Galster et al., 2010; see Sections 2 and 7.1), its rootless character and its close relationship with "ophiolitic" units (Valser slices and Aul unit) is in agreement with this proposed scenario.

\subsection{The Güida-Alpettas zone}

The Gneissquarzite in the Güida-Alpettas zone has previously been interpreted as derived from the erosion of a southerly located emerged land. Since the proximity to the Adula front, the different authors proposed the Adula as a potential source (Kupferschmid, 1977; Probst, 1980; Wyss and Isler, 2007). The homeland of the Güida-Alpettas zone was probably located south of the Adula, being the zone thrusted on top of the Luzzone-Terri nappe, which in turn has an Ultra-Adula origin (Sections 2 and 7.1). Thus the southerly-located emerged land is probably not the Adula rise. But the interpretation of an existing emerged land is still valid and even reinforced by some coal finding associated with the Gneissquarzite (Galster, 2010).

\subsection{The Adula nappe}

Curiously the interpretation of an emerged Adula is still valid. In fact the stratigraphic record in the "Internes Mesozoikum" strongly supports the activity of distributed Normal faults allowing the emersion of at least part of the Adula. Emersion is in particular proved by the siderolithic near the Plattenberg and suggested by Triassic erosion followed by drowning under high-energy conditions (crinoids).

Another interesting point outlined by the new stratigraphic results is the coherency of the stratigraphic record in the Northern Adula nappe. This coherency speaks against a lithospheric mélange created in a subduction channel (e.g. Engi et al., 2001; Trommsdorff, 1990) and suggests that the Northern Adula is a coherent nappe. A possible scenario is that the presence of paleo-faults, systematically associated with the "Internes Mesozoikum", has played a major role in creating the "Internes Mesozoikum". During an early phase of subduction the reactivation and inversion of the faults preserved the basement-cover contact by a mechanism where the sediments onto the hanging block are trapped by its inversion above the footwall. A similar scenario has been proposed by Krayenbuhl and Steck (2009) in order to explain the complex basement-cover relationship in the Jungfrau syncline (External Massifs).

The proposed mechanism could prevent sediments' off scraping and allows the preservation of the cover even in highly deformed nappes submitted to eclogitic conditions.

\section{Discussion on the preorogenic history}

\subsection{The North-Penninic-Triassic: the missing link between the Briançonnais and the Helvetic?}

The Briançonnais character of the Permo-Triassic in the Luzzone-Terri nappe has been demonstrated recently by Galster et al. (2010). The Helvetic character of the Triassic formations in the Gotthard massif and Lucomagno nappe is obvious and already evoked by several workers (Baumer et al., 1961; Brunnschweiler, 1948; Fehr, 1956; Probst, 1980). Which of the two categories of facies represents at best the Triassic characterised by the "dolomie bicolori" that is located in-between? For 
the further discussion we will call the Triassic characterised by the "dolomie bicolori" the North-Penninic-Triassic.

The scarcity of limestones and the abundance of dolomites in the North-Penninic-Triassic argue in favour of a Helvetic character. On the other hand, thanks to its sedimentological characteristics, the "dolomie bicolori" evoke the Champcella Formation at Fanee, which in turn is an external equivalent of the Champcella Formation typical for the Briançonnais Triassic.

The Valser and the Garzott slices are instructive in this regard. With the vermiculated limestones, they share the same basis with the Luzzone (Briançonnais) Triassic but continued upward with the "dolomie bicolori". Then, toward the more external units (Adula and Simano), the St-Triphon Formation is progressively reduced, but the "dolomie bicolori" are still present.

The age of the "dolomie bicolori" is probably Ladinian, as testified by the exceptional fossils founding of Bianconi (1965, pag 574) in the Campolungo area where the "dolomie bicolori" are well expressed in the Simano Triassic (see Bianconi, 1971). Thus the progressive facies transformation and the chronological equivalence support the idea that the "dolomie bicolori" are an external equivalent of the Champcella Formation.

Moreover the following aspects are noteworthy: a) the adjacency of the North-Penninic-Triassic to the Fanee (Briançonnais) Triassic, b) the extremely reduced St-Triphon (Briançonnais) Formation at the basis of the most internal (Valser and Garzott slices) NorthPenninic-Triassic and c) the fact that this reduced (or disappeared) equivalent is stratigraphically followed by a family of Ladinian facies that mimic a reduced Champcella (Briançonnais) formation. Therefore several lines of evidences suggest that the North-PenninicTriassic was deposited on the banks of the great Briançonnais basin. We propose that the units bearing this kind of Triassic represent the external limit of the Briançonnais Triassic paleogeographic domain.

In its most external part, the Simano nappe (which is characterised by the "dolomie bicolori" in its internal part) shares the same Triassic that is normally ascribed to the Helvetic domain. A clear Helvetic Triassic is omnipresent over the immediately adjacent Lucomagno nappe and just to the north in the Gotthard massif (see Section 2).
These observations indicate that, during the Triassic, the Briançonnais paleogeographic domain was located southwards from the Helvetic domain. It has probably been separated from the European plate sensu stricto by Jurassic rifting (see Section 6.3). Therefore, the apparent exotic character of the Briançonnais Jurassic facies (Schardt, 1898) could be explained under this perspective rather than evoking a far travelled origin (e.g. Stampfli, 1993).

\subsection{The Jurassic rifting and the associated subsidence: when and where?}

An apparent astonishing situation that results from the stratigraphic record in the distal European margin, south of the Gotthard, is the absence of strong subsidence during the Middle Jurassic, a period that corresponds with the onset of magmatic activity in the Penninic oceans (e.g. Hauser and Müntener, 2011; Manatschal et al., 2006). This situation is similar to that already documented for the Briançonnais domain and in the Middle Penninic units (e.g. Badoux \& Mercanton, 1962).

In this section first we focus on the timing of rifting and subsidence evolution in the internal Helvetic and Lower Penninic nappes and then we propose some working-hypothesis in order to explain our observations (keeping in mind that, as highlighted by Trümpy (1976, pag. 262), "le role des hypotheses de travail n'est pas celui de fournir des solutions, mais avant tout de poser des questions").

The Jurassic stratigraphic column of the Scopi and Peidener zones in the "Gotthard Massivischer Mesozoikum" finds a natural continuation in that of the Luzzone-Terri nappe (Table 1 and Fig. 8) suggesting that the different units originated from the same Liassic basin. But Helvetic conditions, that during Liassic time extended from the Tavetsch south of the Adula, into the Piz Terri-Lunschania zone, gently disappeared south of the Güida zone, where shallower conditions indicate the presence of the southern border of the Liassic Helvetic basin (Fig. 9).

At the beginning of Middle Jurassic, the area south of the Aar massif was being filled by the Aalenian shales, whose thickness is still remarkable in the Scopi zone ( $500 \mathrm{~m}$ ) but then is reduced drastically in the Peidener and the Piz Terri-Lunschania zone. In many sections the reduction is in part an artefact of tectonic off scraping, but not in the Güida zone, where the Coroi shales never exceed a few metres. If

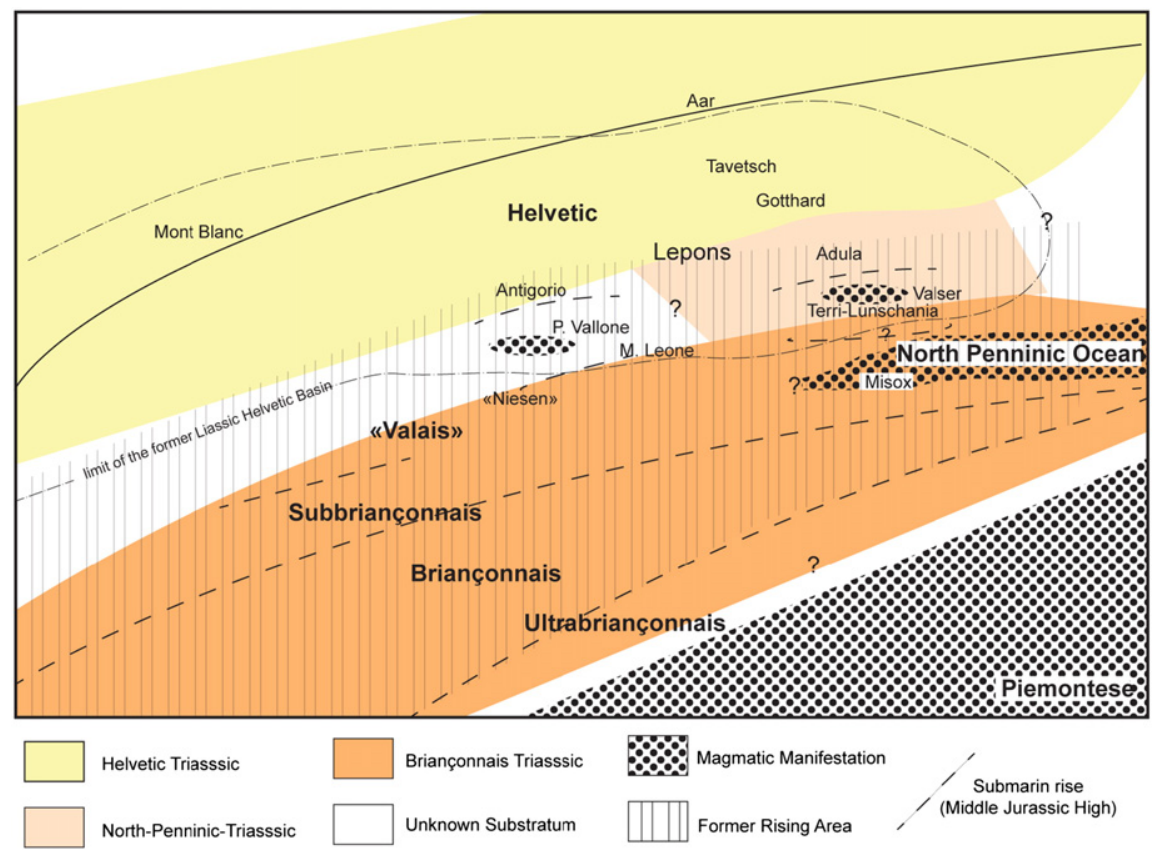

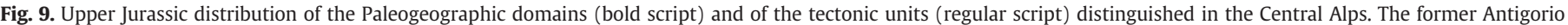

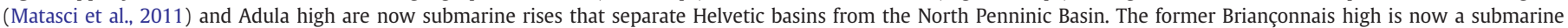

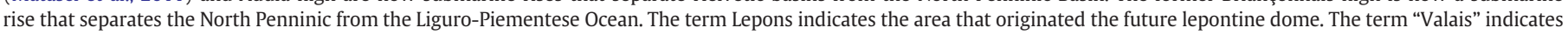
the future location of the Valais Trough (see Section 1). The Triassic Substratum is also represented, with large incertitude. 
during Sinemurian and Pliensbachian time the deepest part of the basin was located in the Luzzone-Terri nappe (cf the Upper Stgir series and the Inferno Formation), during the Toarcian it seems to migrate toward the external part of the basin (Gotthard and Tavetsch). The Middle Jurassic of the internal part instead suffered an inversion and emerged, as testified by the Adula and the Güida-Alpettas stratigraphy (Table 1 and Fig. 8).

This wide zone of emerged land is intimately associated with oceanic crust: the Misox zone and the Valser slices are rich in MORB-type metamafic (Dürr et al., 1993; Steinmann and Stille, 1999). For the Misox zone a Jurassic age is testified by U-Pb dating on zircon ( 161 Ma, Liati et al., 2005), for the Valser slices it is supported by facies analysis (Steinmann, 1994). It is noteworthy that part of the magmatic activity is recorded in tuffites and other volcanoclastic manifestations (Kupferschmid, 1977).

The combination of our tectonostratigraphic data with existing geochemical data suggests that, in the North Penninic basin, in the most distal part of the European margin, crustal thinning, break-off and magmatic activity were coupled with uplift and only moderate localised subsidence.

Classical rifting models (McKenzie, 1978; Wernicke, 1985) fail to explain our observations since they predict strong and rapid subsidence in response of crustal thinning in the most internal part of rifting.

A first hypothesis to account for the observed paleobathymetric evolution is that in the distal European margin the crust was not homogeneously thinned. Several unthinned high (preserved) separated several faultbounded "deep" basins (mostly subducted) characterised by stretched crust.

A second hypothesis is that progressive lithospheric thinning could be compensated by increasing buoyancy, it results in a delayed subsidence even in the most internal part of rifting.

Some recent developments in understanding rifting dynamics seem to support our second hypothesis: Müntener et al. (2010) proposed the creation of a "lithospheric sponge" by trapping in the mantle part of the liquid produced during rift-induced decompression melting in a non-optimal extraction system. The resulting lithospheric mantle is compositionally buoyant and able to inhibit the subsidence of thinned continental crust. Additionally Kaus et al. (2005) and Simon and Podladchikov (2008) highlighted the effect of subsolidus phase transition (e.g. spinel $\rightarrow$ plagioclase) on mantle density, which is reduced during thinning and asthenospheric upwelling and calculated some consequences for the uplift vs subsidence of the overlaying crust and sedimentary basins.

\subsection{The rising area between the Helvetic distal margin and the Briançonnais}

The above-mentioned effects on the evolution of distal margins could explain the generalised presence of emerged lands (or islets) during the Middle Jurassic in the Distal European Margin of the Alps and in the Briançonnais domain. In fact there is evidence for several highs in the distal part of the margin even further to the west of our study area (Fig. 9), where on the same transect we find again the Briançonnais rise, in a Middle Penninic Position (Badoux \& Mercanton, 1962), the Monte Leone (Carrupt, 2003) and the Antigorio (Matasci et al., 2011) highs in a Lower Penninic position. In this case "Middle Jurassic" metamafics are present in the Lower Penninic Pizzo del Vallone nappe (Carrupt, 2003). Even more to the west, the Subbriançonnais domain got a bathonian detrital input ("Quarzporphyr-Geröllen") from the north (Furrer, 1977, 1979), from a potential Valaisan high (Septfontaine, 1983).

The "rising area" in the middle of the Alpine rifting and extending from the distal Helvetic margin to the Briançonnais (already splendidly illustrated by Trümpy (1965, pag. 577), see also Sengör \& Bernoulli, 2011 Fig. 6 ) is the best exposed field example of inhibited or delayed subsidence in future deep-water margins.

In the distal European margin the end of the subsidence inhibition and the beginning of generalised subsidence started probably just before the Upper Jurassic. The omnipresent Upper Jurassic limestone (Quinten Formation) on the proximal and distal Helvetic margin testifies the accomplishment of this event. The recently reported hydrothermal activity at $\sim 162 \mathrm{Ma}$ in the proximal margin and Jura Plateau (Efimenko, 2011) is in agreement and reinforces our scenario.

\subsection{The Plattenberg and Garzott breccias: a second rifting or a protracted history?}

At the Hennasädel the Adula shows post-Triassic erosion, drowning and subsequent sealing with Upper Jurassic post-rift sediments of South-Helvetic type (Quinten Formation or even better the Antabia group, see Section 4.8). At Plattenberg it is possible to deduce that the beginning of the drowning phase is followed by the activity of scarp faults. Probably this phase lasted until late Jurassic as the breccia follows in time the generalised emersion and since upwards it bears some intercalations of pure marble suggesting synchronism with the Hennasädel Upper Jurassic marble.

The Garzott slices show an analogue scenario. The two units were probably separated by the Valser slices (see later), which contain "ophiolitic" material originated from a depleted mantle source (Dürr et al., 1993; Steinmann, 1994; Steinmann and Stille, 1999).

Even if located further to the south the Güida-Alpettas zone shares some analogies with the Adula-Garzott problem. There the postAalenian clastic sequence is separated in two parts by several metres of marls and marly limestones (see Section 3.5.3 and Table 1), in other words a first period of important tectonic activity and emersion is separated by a phase of quiescence from a second period of erosion and resedimentation.

The basaltic manifestation in the North Penninic domain is followed by thousand of metres of mostly Cretaceous calcschists (Pantic \& Gannser, 1977; Pantic and Isler, 1978, 1981; Steinmann, 1994 p. 92). It results that in the Central Alps transect, the first evidence of strong subsidence in the most distal European margin and adjacent oceanic domain is not older than the Late Jurassic.

The Middle Jurassic uplift and the late Jurassic generalised subsidence are separated by a spasmodic distensive phase during which submarine breccia (Plattenberg and Garzott), MORB (Misox) and allochtones (Garzott and maybe Luzzone and Güida-Alpettas) were created.

This particular protracted history is not unique to the studied transect. Noteworthy are the analogies existing between the Niesen Middle Jurassic substratum in the Prealps (Badoux and Homewood, 1978; Ringgerberg et al., 2001) and the Güida-Alpettas "Middle Jurassic" (in both there are two detrital inputs separated by a more fine grained and less detrital level). Moreover, several enigmatic late Middle Jurassic-early Upper Jurassic clastic series and Breccias characterise the Lower and Middle Penninic domains, but these are missing in the more external domains, where breccias are quite older (Trümpy, 1975). As examples of enigmatic Penninic breccias we can quote the Bréches du Télégraphes and the Nielard Breccias (Barbier, 1948), the Schamser breccias (Schmid et al., 1990), the Falknis and the Tasna breccias (Gruner, 1981) and the most famous "Brèche Supérieur" in the Breccia Nappe (Schroeder, 1939), which is separated from the Middle Jurassic "Brèche Inférieur" by the "Schistes Ardoisiers". The domains interested by these latecomer breccias are also affected by a later tectonic activity as reported by Felber (1984) in the Klippen of Central Switzerland, by Septfontaine (1983) in the Préalpes Médianes and more recently by Bertok et al. (2011) in the ligurian Briançonnais.

Thus since the scale involved is larger than the local or regional context, the explanation should be of first order (Fig. 10).

We explain this protracted history as follows (partly inspired by Manatschal et al. (2006, 2007), Mohn et al. (2010) and Péron-Pinvidic et al. (2007), Péron-Pinvidic and Manatschal, 2009 and Péron-Pinvidic et al., 2010):

The early phase of rifting is responsible for delocalised crustal thinning and the formation of the Helvetic basins. 
Pliensbachian-Toarcian

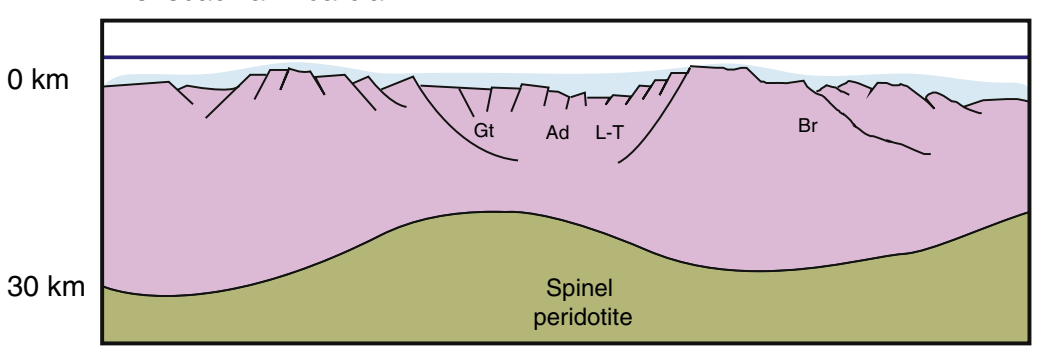

Bajocian-Bathonian

$0 \mathrm{~km}$

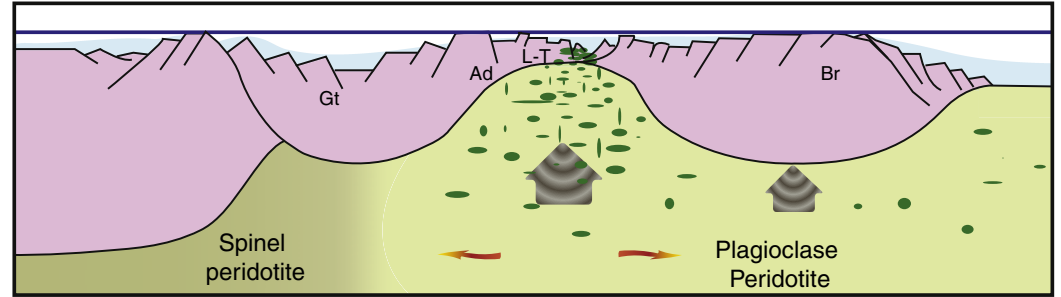

Kimmeridgian-Tithonian

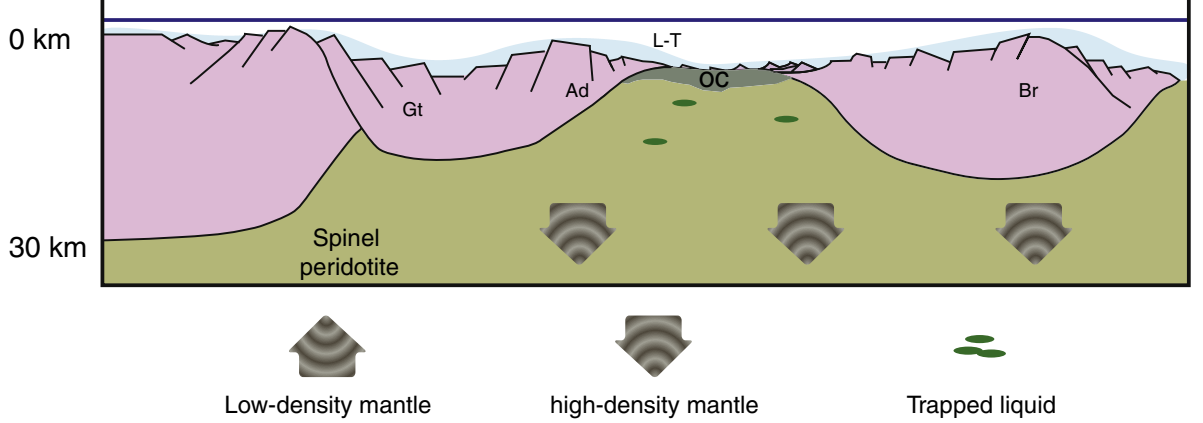

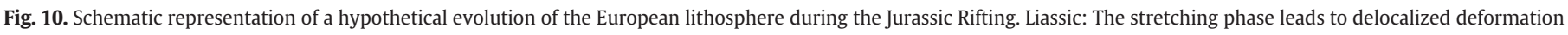

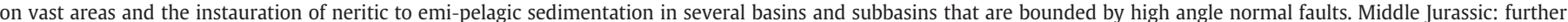

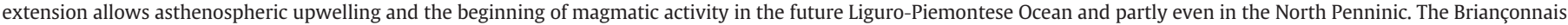

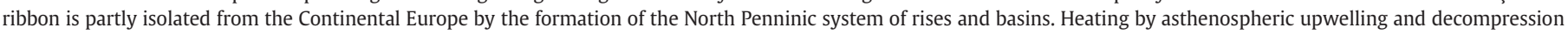

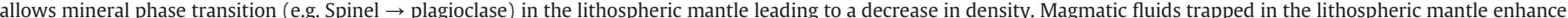

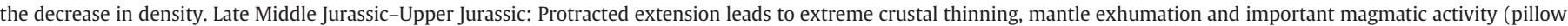

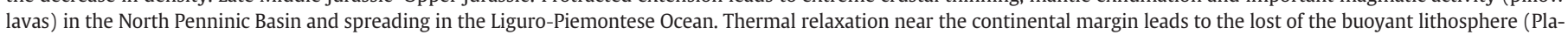

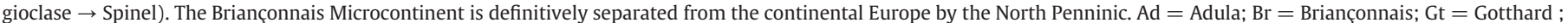
$\mathrm{L}-\mathrm{T}=$ Luzzone-Terri; oc $=$ oceanic crust.

The Lower and Middle Jurassic lithospheric thinning is responsible for the creation of the rising area between the internal South Helvetic and the Briançonnais domains by the mechanism evocated in Section 6.2 (heating, phase's transition and "lithospheric sponge"), the opening of the Liguro-Piemontese ocean and localised magmatic activity in the North Penninic. The next advanced phase of rifting abandoned proximal areas and prograded in the most internal part (a scenario predicted by Péron-Pinvidic et al., 2007, Péron-Pinvidic and Manatschal, 2009), the consequence of this is the late Middle Jurassic and early Upper Jurassic spasmodic extension, which culminated with stronger magmatic activity (pillow lavas, e.g. Tomül). This phase leads to the delamination of the previously existing rises (e.g. Adula and Briançonnais) and is associated with the loss of the "buoyant sponge" and "phases transition" positive buoyancy effects (see above). The direct consequences of the resulting subsidence in this previously mistreated area are the thick and monotonous North Penninic Bündnerschiefer series, which were deposited over different pre- to syn-rift sequences and that are now stacked in many nappes and melanges zones within the Lower Penninic (Lucomagno and Molare-Dangio of Probst, the Garzott calcschists of this contribution, The Bündnerschiefer in the Valser, Aul and Grava mélanges, The Grava and Tomül Bündnerschiefer).

\section{Discussion on the orogenic history}

Given the complex tectonic situation around the Adula front (Fig. 2), the precise position of the Piz Terri-Lunschania zone in the tectonostratigraphy of the Central Alps is controversial (cf. Baumer, 1964; Cavargna-Sani et al., 2010b; Egli, 1966; Galster et al., 2010; Jenny et al., 1923; Kupferschmid, 1977; Probst, 1980; Schmid et al., 1996; Wiederkehr et al., 2008).

The Ultra-Adula origin of the zone, suggested by Cavargna-Sani et al. (2010b) and Galster et al. (2010) is confirmed by our results. The discovery of the Garzott slices and the understanding of the original mechanical behaviour of the Piz Terri-Lunschania zone (fold ramps) clarify the complexity of the zone and give coherency even at the apparently complex tectonic situation.

\subsection{The Piz Terri-Lunschania zone: an internal klippen-belt}

The Grava unit is thrusted above the Piz Terri-Lunschania zone and is rooted in the Misox zone, above the Aul unit, the Valser slices and the Adula nappe. However it is folded below the Adula front for several kilometres. To the north, the Grava unit is thrusted above the External Massifs and the Infra-Helvetic nappes. The part of the unit 


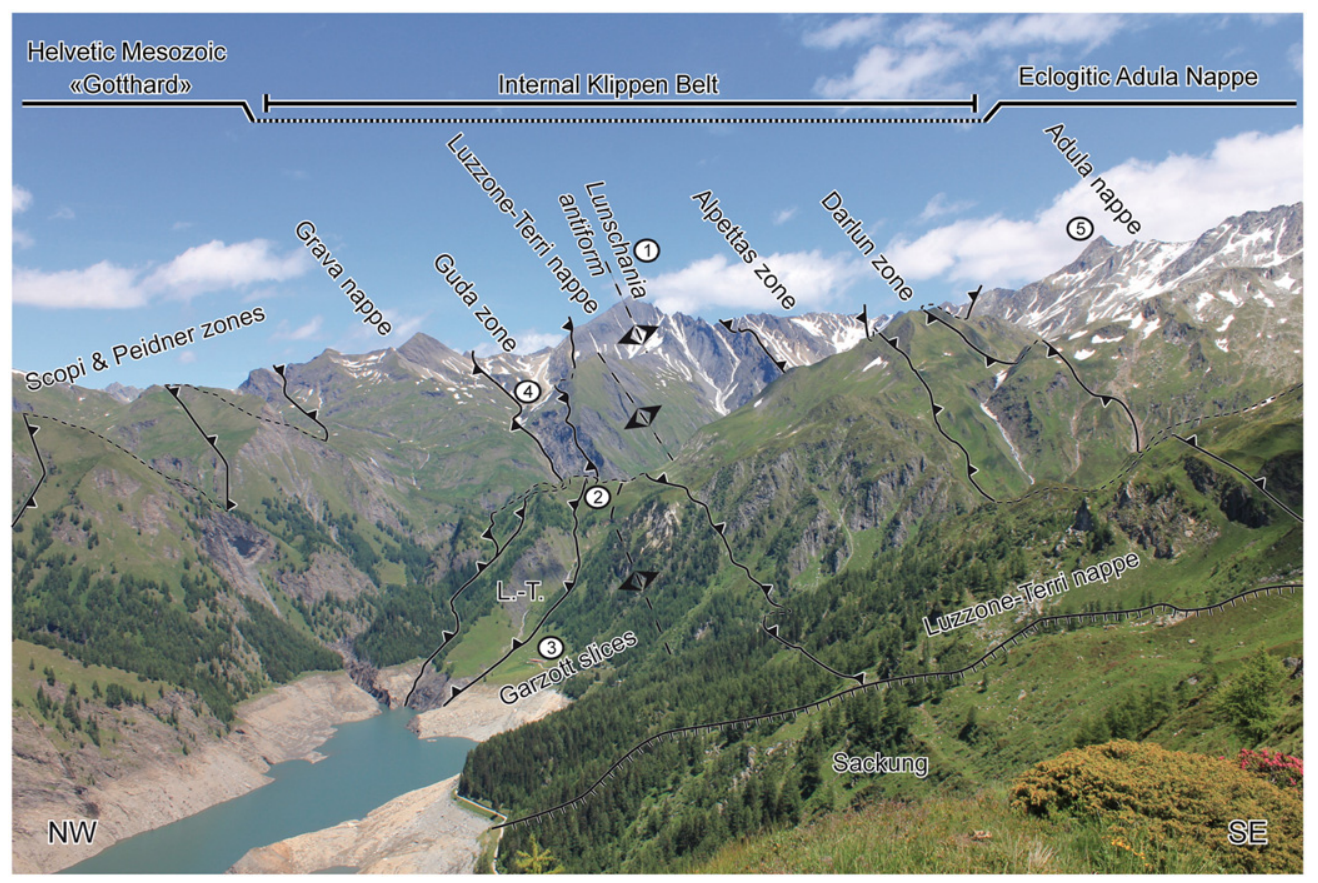

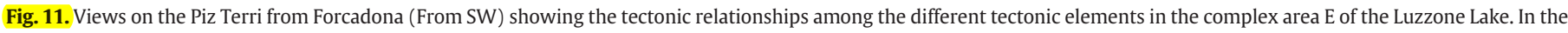

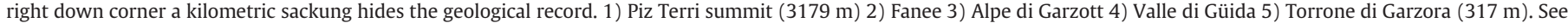
text for further explanation. The geometric relationships among the different units are illustrated in the section of Fig. $2 \mathrm{~b}$.

folded below the Adula nappe is a portion of the thrusting plane and it is probably not the original front. The rootless units located below this plane could be part of the same tectonic system: an "overridingcomplex" that, originated from the North Penninic basin, has been thrusted above the distal and the proximal Helvetic margin. The Piz-Terri-Lunschania zone could be part of the "overridingcomplex". In fact the "root-zone" of the Piz Terri-Lunschania zone is apparently sandwitched and smashed between the Adula nappe above and the overturned Grava unit below, a situation that gives to the Piz Terri-Lunschania zone a rootless character.

The pre-rift stratigraphy from the Briançonnais carbonate platform to the Helvetic lands is extremely coherent if an Ultra-Adula origin of the Piz Terri-Lunschania zone is considered but become too complex and partitioned for the quiet Triassic period if the zone is regarded as rooted below the Adula nappe. For paleogeographic coherency the Luzzone-Terri nappe should be rooted between the Aul unit (where the Triassic comprises several tens of metres of (vermiculated?) limestones) and the Garzott slices, the Garzott slices on their side should be rooted between the Luzzone-Terri nappe and the Valser slices. The Valser slices are rooted between the Aul unit and the Adula nappe. Thus the tectonic order from below to above is: Adula nappe, Valser slices, Garzott slices, Luzzone-Terri nappe, Aul unit and Grava unit. The Güida-Alpettas zone is tectonically intercalated between the Luzzone-Terri nappe and the Grava unit. Its precise position, relative to the Aul unit is still unknown.

The Darlun zone consists of several imbricated slices thrusted above the Luzzone-Terri nappe. Northeastward it's flexured around the Adula front above the overturned internal Alpettas zone (Figs. 2 and 11). The flexuration around the overlaying nappe is unusual for an originally underlying body and suggests that the Darlun zone is located above the Adula nappe and that it represents the virtual connection between the Piz Terri-Lunschania zone and its homeland. The former connection has been dismembered and hidden by the advancing Adula nappe.

In summary, the Piz Terri-Lunschania zone is considered as a klippe of Ultra-Adula origin that, together with the Grava unit, "climbed over" the Adula nappe during early subduction and then has finally been overtaken by the Adula front during the final uplift of the eclogitic nappe. The Piz Terri-Lunschania zone is thus part of an "Internal
Klippen Belt" (Fig. 11) pinched between the External Massif (Gotthard) and the eclogitic unit (Adula nappe) by the uplift of the latter.

\subsection{The Garzott fault: the escape from deep subduction}

The existence of the Luzzone-Terri fold ramps suggests us the manner in which the Luzzone-Terri nappe achieves the difference in displacement with the Adula nappe. Fold ramps obviously need a ramp. The latter is in direct contact with the deepest part of the developing thrusting complex. In the case of the Penninic nappes of Ultra-Adula origin, the deepest portion of the complex is represented by the Garzott slices, in an advanced position, and by the Lower Valser slices in a recessed position. Both are slices (Schuppenzones) and both share the same typology of North-Penninic-Triassic facies (which evolve quickly from internal to external area), thus they can be seen as adjacent during their pre-orogenic history (Triassic) and then genetically linked during the orogenesis (Schuppenzonen). We have suggested a supra-detachment affinity for the Jurassic stratigraphic record in the Garzott slices (Section 5.1), close relationships between oceanic (Jurassic) and continental rocks characterise the Valser slices (Dürr et al., 1993; Kupferschmid, 1977; Steinmann and Stille, 1999; Wyss and Isler, 2007), suggesting a transition from the continent to the ocean (OCT). Thus proximity and a genetic link between the Garzott "supra-detachment" and the Valser "OCT" seem to exist even during the Jurassic.

Considered the evolution of the Piz Terri-Lunschania zone and that of the Grava unit (see above) the most suitable scenario is that the Garzott slices together with the Valser slices are part of the ramp that allowed the overriding (from an Ultra-Adula to the current position); they have been "sampled" by the advancing penninic mass.

During the pre-orogenic history the Garzott slices are part of a supra-detachment system, thus they are separated from an underlying exhumed basement by a detachment system (of which the Garzott fault is part). Since this basement is not currently present (the peculiarity of the Misox zone, compared to the South Penninic ocean, is the scarcity of preserved exhumed mantle rocks) we speculate that it has been subducted with the Adula nappe below the ramp (the rodingite of Alpe Duria and Cima di Gagnone are good candidates, as the Alpe Arami or Chiavenna peridotite and the mafic and ultramafic in the Southern 
Steep Belt). Thus a logical conclusion is that the Jurassic detachment, which allowed crustal thinning during rifting, acted as a ramp for the "detached" units during the Tertiary collision.

\section{Conclusion}

In this contribution we reported new tectonostratigraphic information from the Central Alps, along a profile located between the Helvetic External Massifs and the Briançonnais Middle Penninic units. Our results suggest that the Jurassic rifting separated the Briançonnais paleogeographic domains from the Helvetic margin by complex and protracted extension. The future deep-water rifted margin stayed at shallower conditions during rifting paroxysm and the first magmatic activity. The distal margin was characterised by a diffuse rising area with only moderately subsiding basins above a thinned continental and proto-oceanic crust. This apparent contradiction is explained by the isostatic response of the lithosphere to density changes in the mantle by heating, mineral phase transition and liquid trapping and by the fact that extreme thinning occurred in a second protracted step. The resulting system is isostatically buoyant. The lost of the buoyancy forces and the protracted extension are responsible for the delamination of the rising area followed by strong subsidence. The hints of this second phase are recorded in the enigmatic "Callovo-Oxfordian" breccias distributed in the Penninic domain all along the chain. The northern border of the rising area was characterised by a Triassic substratum different from the typical Briançonnais Triassic and even from the Helvetic one. This new group of Triassic facies is defined here for the first time and is called the North-Penninic-Triassic. This particular Triassic, characterised by the Ladinian "dolomie bicolori" was deposited on the banks of the Briançonnais basin directly south of the Helvetic domain, thus is likely to have acted as connection between the Briançonnais carbonate platform and the Helvetic lands. The eclogitic Adula nappe is characterised by this particular stratigraphic association, this, together with the coherency of the stratigraphic record in the Northern Adula nappe and surrounding areas, questions the idea of a lithospheric mélange in the Adula nappe. The great and famous eclogitic nappe is more likely to be a coherent alpine nappe that during Mesozoic time experienced a peculiar geodynamic history in the frame of alpine paleogeography. During Tertiary collision the Adula nappe acted as a single tectonic object in a coherent tectonic context. In this scenario the reactivation of Mesozoic extensional structures played a major role in allowing Adula subduction, the Penninic overriding above it and in creating the structural complexity of the Central Alps.

\section{Acknowledgments}

This work has been partly supported by the Swiss National Science Foundation (frant 200021_132460), We thank Alfred Isler for having provided us with a copy of the unpublished manuscript of A. Uhr. Fruitfull discussions with Aymon Baud, Jean Guex, Geoffroy Mohn, Othmar Müntener, Phil Picuri, Caroline Wilhem and the comments of Marco Beltrando and one anonymous reviewer helped us to improve considerably our work. We are grateful to the Museo Cantonale di Storia Naturale at Lugano for authorization to collect samples in Ticino.

\section{References}

Ammann, P., 1973. Geologia e petrografia della regione del Pizzo Molare. Ph.D. diss. ETHZ Nr. 5282, ETH Zurich.

Anatra, S., 1986. Les faciès pélagiques de l'Ultrahelvétique entre Arve et Simme. Thèse Université de Fribourg, 206pp.

Argand, E., 1918. Zur Tektonic des Val Blegno. Eclogae Geologicae Helvetiae 14 (5), 685-686.

Aubert de la Rue, E., Weidmann, M., 1966. Découverte nouvelles d'ammonites dans la couverture sédimentaire du massif du Gotthard. Eclogae Geologicae Helvetiae 59 (2).
Avanzini, M., Cavin, L., 2009. A new Isochirotherium trackway from the Triassic of Vieux Emosson, SW Switzerland: stratigraphic implications. Swiss Journal of Geosciences 102 (2), 353-361

Badoux, H., Homewood, P., 1978. Le soubassement de la nappe du Niesen dans la région du Sépey (Alpes vaudoises). Bulletin de Géologie Lausanne 228.

Badoux, H., Mercanton, C.H., 1962. Essai sur l'évolution tectonique des Préalpes médianes du Chablais. Eclogae Geologicae Helvetiae 55 (1), 135-188.

Barbier, R., 1948. Les Zones Ultradauphinoise et Subbriançonnaise entre l'Arc et l'Isère. Mémoires Service de la Carte Géologique de la France N³7, 291 pp.

Baud A., 1976. Les terriers de Crustacés décapodes et l'origine de certains faciès du Trias carbonaté. Eclogae Geologicae Helvetiae 69/2, and Bulletin de Géologie Lausanne 219: 415-424.

Baud, A., 1987. Stratigraphie et sédimentologie des calcaires de Saint-Triphon (Trias, Préalpes, Suisse et France). Mémoires de Géologie Lausanne 1 (322 pp.).

Baud, A., Masson, H., 1975. Preuves d'une tectonique liasique dans le domaine briançonnais: faillées conjuguées et paleokarst à Saint-Triphon (Préalpes Médianes, Suisse). Eclogae Geologicae Helvetiae 68 (1), 131-145.

Baud, A., Mégard-Galli, J., 1975. Evolution d'un bassin carbonaté du domaine alpin durant la phase pré-océanique: cycles et séquences dans le Trias de la zone briançonnaise des. Alpes occidentales et des Préalpes. 9e Congr. intern. Sédiment. (Nice), 5, pp. 45-50.

Baumer, A., 1964. Geologie der gotthardmassivisch-penninischen Grenzregion im oberen Bleniotal. Geologie der Blenio-Kraftwerke. Beiträge zur Geologie der Schweiz Geotechnische series 39 (105 pp.).

Baumer, A., Frey, J.D., Jung, W., Uhr, A., 1961. Die Sedimentbedeckung des Gotthard-Massivs zwischen oberen Bleniotal und Lugnez. Eclogae Geologicae Helvetiae 54 (2), 478-491.

Berger A., Mer colli I., Engi M., 2007. Tectonic and Petrographic Map of the Central Lepontine Alps 1 : 100 000, Explanatory notes. Carta Geologica Speciale 127. Swisstopo, 38 pp.

Berger, A., Mercolli, I., 2006. Tectonic and Petrographic map of the Central Lepontine Alps 1:100 000 (Map sheet 43 Sopra Ceneri). Carta Geologica Speciale 127. Bern: Swisstopo.

Bertok, C., Martire, L., Perotti, E., d'Atri, A., Piana, F., 2011. Middle-Late Jurassic syndepositional tectonics recorded in the Ligurian Briançonnais succession (Marguareis-Mongioie area, Ligurian Alps, NW Italy). Swiss Journal of Geosciences 104 (2), 237-255.

Bianconi, F., 1965. Resti fossili in rocce mesometamorfiche della regione del Campolungo. Schweizerische Mineralogische und Petrographische Mitteilungen 45/2, $571-596$

Bianconi, F., 1971. Geologia e petrografia della regione del Campolungo. Materiali Carta Geologica Svizzera [N.S.] 142 (238 pp.).

Brunnschweiler, R.O., 1948. Beitrage zur Kenntnis der Helvetischen Trias ostlich des Klausespasses. Diss. Univ. Zürich.

Carrupt, E., 2003. New stratigraphic, structural and geochemical data from the Val Formazza-Binntal area (Central Alps). Mémoires de Géologie Lausanne 41, 118.

Cavargna-Sani, M., Epard, J.-L., Bussy, F., Ulianov, A., 2010a. Zircon U/Pb dating of the Late Carboniferous Zervreila Orthogneiss, Adula Nappe. Abstract Swiss Geosciences Meeting Fribourg (http://my.unil.ch/serval/document/BIB_8E3BAD976040.pdf).

Cavargna -Sani M., Epard J.-L. , Masson H., 2010a. Discovery of fossils in the Adula nappe, new stratigraphic data and tectonic consequences (Central Alps). Bulletin de la Société Vaudoise des Sciences Naturelles 92: 77-84 // Bulletin de Géologie Lausanne 368 (http://www3.unil.ch/wpmu/svsn/files/2011/06/03_Cavargna_92. 2_web.pdf).

Dewey, J.F., Helman, M.L., Turco, E., Hutton, D.H., Knott, S.D., 1989. Kinematics of the western Mediterranean. In: Coward, et al. (Ed.), Alpine Tectonics Geological Society. Special Publication 45, 265-283.

Dössegger, R., Trümpy, R., 1972. Permian of Switzerland. In: Falke, H. (Ed.), Rotliegend. : Essays on European Lower Permian. Brill, Leiden, pp. 189-213.

Dürr, S.B., Ring, U., Frisch, W., 1993. Geochemistry and geodynamic significance of North Penninic ophiolites from the Central Alps. Schweizerische Mineralogische und Petrographische Mitteilungen 73, 407-409.

Efimenko, N., 2011. Origin of cadmium enrichments in carbonate rocks deposited in the Alpine Tethys area during the Middle-Late Jurassic. Unpublished Phd thesis, University of Lausanne.

Egli, W., 1966. Geologisch-petrographische Untersuchungen in der NW-Aduladecke und in der Sojaschuppe (Bleniotal, Kanton Tessin). Mitteilungen Geologische Institut ETHZ [N.F.] 47 (159 pp.)

Engi, M., Berger, A., Roselle, G., 2001. The role of the tectonic accretion channel in collisional orogeny. Geology 29, 1143-1146.

Epard, J.-L., 1990. La nappe de Morcles au sud-ouest du Mont-Blanc. Mémoires de Géologie Lausanne 8, 165p.

Etter, U., 1987. Stratigraphische und strukturgeologische Untersuchungen im Gotthardmassivischen Mesozoikum zwischen dem Lukmanierpass und der Gegend von Ilanz. Dissert. Univ. Bern, 162 pp.

Fehr, A., 1956. Petrographie und Geologie des Gebietes zwischen val Zavragia - Piz Cavel und Obersaxen - Lumbrein (Gotthard-Massiv-Ostende). Schweizerische Mineralogische und Petrographische Mitteilungen 36 (2), 351-452.

FELBER P.J., 1984. Der Dogger der Zentralschweizer Klippen. Diss. ETH Nr. 7506, $156 \mathrm{pp}$.

Fox, J.S., 1975. Three-dimensional isograds from the Lukmanier-Pass, Switzerland, and their tectonic significance. Geological Magazine 112, 547-564.

Frey, J.D., 1967. Geologie des Greinagebietes. Beitraege Geologische Karte Schweiz [N.F.] 131 (112 pp.).

Frey, M., 1969. Die Metamorphose des Keupers vom Tafeljura bis zum Lukanier Gebiet. Beiträge zur Geologischen Karte der Schweiz [N.F.] 137 (160 pp.).

Frey, M., 1978. Progressive low-grade metamorphism of a black shale formation, Central Swiss Alps, with special reference to pyrophyllite and margarite bearing assemblages. Journal of Petrology 19, 95-135. 
Frisch, W., 1979. Tectonic progradation and plate tectonic evolution of the Alps. Tectonophysics 60 (3-4), 121-139.

Froitzheim, N., Eberli, G.P., 1990. Extensional detachment faulting in the evolution of a Tethys passive continental margin, Eastern Alps, Switzerland. Geological Society of America Bulletin 102 (9), 1297-1308.

Furrer, U., 1977. Stratigraphie des Doggers der Östlichen Préalpes médianes. Diss. Univ. Bern, Universitäts-Druckerei Bern.

Furrer, U., 1979. Stratigraphie des Doggers der Östlichen Préalpes médianes. Eclogae Geologicae Helvetiae 72 (3), 623-672.

Galli, A., Le Bayon, B., Schmidt, M.W., Burg, J.-P., Reusser, E., Sergeev, E.A., Larionov, A. 2012. U-Pb zircon dating of the Gruf Complex: disclosing the late Variscan granulitic lower crust of Europe stranded in the Central Alps. Contribution to Mineralogy and Petrology 163 (2), 353-378.

Galster, F., 2010. Stratigraphie des zones du Piz Terri-Lunschania et de Soja, Alpes Centrales (Suisse). Unpublished Master Thesis, University of Lausanne $211 \mathrm{pp}$.

Galster, F., Epard, J.-L., Masson, H., 2010. The Soja and Luzzone-Terri nappes: Discovery of a Briançonnais element below the front of the Adula nappe (NE Ticino, Central Alps). Bulletin de la Société Vaudoise Sciences Naturelles 92, 61-75 // Bulletin de Géologie Lausanne 368 (http://www3.unil.ch/wpmu/svsn/files/2011/06/02_Galster_92.2_web.pdf).

Gansser, A., 1937. Der Nordrand der Tambodecke. Schweizerische Mineralogische und Petrographische Mitteilungen 17, 291-522.

Genier, F., Epard, J.-L., Bussy, F., Magna, T., 2008. Lithostratigraphy and U-Pb zircon dating in the overturned limb of the Siviez-Mischabel nappe: a new key for Middle Penninic nappe geometry. Swiss Journal of Geosciences 101, 431-452.

Geyer, O.F., 1977. Die "Lithiotis-Kalke" im Bereich der unterjurassischen Tethys. Neues Jahrbuch fur Geologie und Palaontologie Abhandlungen 153, 304-340.

Gisler, C., Hochuli, P.A., Ramseyer, K., Bläsi, H., Schlunegger, F., 2007. Sedimentological and palynological constraints on the basal Triassic sequence in Central Switzerland. Swiss Journal of Geosciences 100 (2), 263-272.

Gruner, U., 1981. Die jurassischen Breccien der Falknis-Decke und altersaequivalente Einheiten in Graubünden. Beiträge zur Geologische Karte der Schweiz [N.F.] 154 (136 pp.).

Hauser, A.-C., Müntener, O., 2011. New age constraints on the opening of the PiemontLigurian Ocean (Tasna-Nauders area, $\mathrm{CH}-\mathrm{A}$ ). Abstract Swiss Geosciences Meeting Zürich.

Heinrich, C.A., 1982. Kyanite-eclogite to amphibolite facies evolution of hydrous mafic and pelitic rocks, Adula-nappe, Central Alps. Contributions to Mineralogy and $\mathrm{Pe}-$ trology $81,30-38$.

Heinrich, C.A., 1986. Eclogite facies regional metamorphism of hydrous mafic rock in the Central Alpine Adula Nappe. Journal of Petrology 27, 123-154.

Herwartz, D., Nagel, T.J., Munker, C., Scherer, E.E., Froitzheim, N., 2011. Tracing two orogenic cycles in one eclogite sample by Lu-Hf garnet chronometry. Nature Geoscience 4, 178-183.

Jenny, H., Frischknecht, G., Kopp, J., 1923. Geologie der Adula. Beiträge zur Geologische Karte der Schweiz [N.F.] 51 (123 pp.)

Jung, W., 1963. Die mesozoischen Sedimente am Südostrand des Gotthard-Massivs (zwischen Plaun la Greina und Versam). Eclogae Geologicae Helvetiae 56 (2), 653-754.

Kaus, B.J.P., Connolly, J.A.D., Podladchikov, Y.Y., Schmalholz, S.M., 2005. Effect of mineral phase transitions on sedimentary basin subsidence and uplift. Earth and Planetary Science Letters 233, 213-228.

Krayenbuhl, T., Steck, A., 2009. Structure and kinematics of the Jungfrau syncline, Faflertal (Valais, Alps), and its regional significance. Swiss Journal of Geosciences 102, 441-456.

Kugler, C., 1987. Die Wildegg-Formation im Ostjura und die Schilt-Formation im östlichen Helvetikum; ein Vergleich. Mitteilungen aus dem Geologischen Institut der ETH und der Universität Zürich, 159 (209 pp.).

Kupferschmid, C., 1977. Geologie auf der Lugnezer Seite der Piz Aul-Gruppe. Eclogae Geologicae Helvetiae 70 (1), 1-58.

Lavier, L., Manatschal, G., 2006. Mechanism to thin continental lithosphere at magma poor margins. Nature 440, 324-328.

Liati, A., Froitzheim, N., Fanning, C.M., 2005. Jurassic ophiolites within the Valais domain of the Western and Central Alps: geochronological evidence for re-rifting of oceanic crust. Contributions to Mineralogy and Petrology 149 (4), 446-461.

Liati, A., Gebauer, D., Fanning, C.M., 2009. Geochronological evolution of HP metamorphic rocks of the Adula nappe, Central Alps, in pre-Alpine and Alpine subduction cycles. Journal of Geological Society of London 166 (4), 797-810.

Liskay, M., 1965. Geologie der Sedimentbedeckung des Südwestlichen GotthardMassivs in Oberwallis. Eclogae Geologicae Helvetiae 58 (2).

Loup, B., 1992. Evolution de la partie septentrionale du domaine helvétique en Suisse occidentale au Trias et au Lias: contrôle par subsidence thermique et variations du niveau marin, 12. Publ. Dépt. Géol. Pal. Univ, Genève (247 pp.).

Löw, S., 1987. Die tektono-metamorphe Entwicklung der nördlichen Adula-Decke. Beiträge zur Geologischen Karte der Schweiz [N.F.] 161 (84 pp.).

Manatschal, G., Engström, A., Desmurs, L., Schaltegger, U., Cosca, M., Müntener, O. Bernoulli, D., 2006. What is the tectono-metamorphic evolution of continental break-up: the example of the Tasna ocean-continent transition. Journal of Structural Geology 28 (10), 1849-1869.

Manatschal, G., Müntener, O., Lavier, L.L., Minshull, T.A., Péron-Pinvidic, G., 2007. Observations from the Alpine Tethys and Iberia-Newfoundland margins pertinent to the interpretation of continental breakup. In: Karner, G.D., Manatschal, G. Pinhero, L.M. (Eds.), Imaging, Mapping and Modelling Continental Lithosphere Extension and BreakupGeological Society of London Special Publications 282, 291-324.

Masini, E., Manatschal, G., Mohn, G., Ghienne, J.-F., Lafont, F., 2011. The tectonosedimentary evolution of a supra-detachment rift basin at a deep-water magma- poor rifted margin: the example of the Samedan Basin preserved in the Err nappe in SE Switzerland. Basin Research 23 (6), 652-677.

Masson, H., Bussy, F., Eichenberger, M., Giroud, N., Meilhac, C., Presniakov, S., 2008 Early Carboniferous age of the Versoyen ophiolites and consequences: nonexistence of a "Valais ocean» (Lower Penninic, western Alps). Bulletin de la Société Géologique de France 179 (4), 337-355.

Matasci, B., Epard, J.-L., Masson, H., 2011. The Teggiolo zone: a key to the HelveticPenninic connection (stratigraphy and tectonics in the Val Bavona, Ticino, Central Alps). Swiss Journal of Geosciences 104 (2), 257-283.

Maxelon, M., Mancktelow, N.S., 2005. Three-dimensional geometry and tectonostratigraphy of the Pennine zone, Central Alps, Switzerland and Northern Italy. Earth-Science Reviews 71, 171-227.

McKenzie, D., 1978. Some remarks on the development of sedimentary basins. Earth and Planetary Science Letters 40, 25-32.

Mégard-Galli, J., 1972. Données nouvelles sur le Carnien dans la zone briançonnaise entre Briançon et la vallée du Guil: conséquences tectoniques et paléogéographiques. Géologie Alpine 48, 131-142.

Mégard-Galli, J., Baud, A., 1977. Le Trias moyen et supérieur des Alpes nordoccidentales et occidentales: données nouvelles et corrélations stratigraphiques. Bulletin BRGM (2) IV/3, 233-250.

Mohn, G., Manatschal, G., Müntener, O., Beltrando, M., Masini, E., 2010. Unravelling the interaction between tectonic and sedimentary processes during lithospheric thinning in the Alpine Tethys margins. International Journal of Earth Sciences 99 (Suppl. 1), 75-101.

Müntener, O., Manatschal, G., Desmurs, L., Pettke, T., 2010. Formation of refertilized peridotite: geochemisty, spatial variability and the importance- of a 'lithospherie sponge' during rifting and thinning of the continental crust Journal of Petrology $51(1-2), 255-294$.

Nabholz, W.K., 1945. Geologie der Bündnerschiefergebirge zwischen Rheinwald, Valser- und Safiental. Eclogae Geologicae Helvetiae 38 (1), 1-119.

Nagel, T.J., 2008. Subduction, collision and exhumation recorded in the Adula nappe central Alps. In: Siegesmund, S., Fügenschuh, B., Froitzheim, N. (Eds.), Tectonic Aspects of the Alpine-Dinaride-Carpathian System: Geological Society, London, Special Publications, 298, pp. 365-392.

Niggli, E., 1970. Alpine Metamorphose und alpine Gebirgsbildung. Fortschritte der Mineralogie 47, 16-26.

Pantic, N., Gannser, A., 1977. Palynologische Untersuchungen im BündnerschieferEclogae Geologicae Helvetiae 70/1, 59-81.

Pantic, N., Isler, A., 1978. Palynologische Untersuchungen in Bündnerschiefern (II) Eclogae Geologicae Helvetiae 71, 447-465.

Pantic, N., Isler, A., 1981. Palynologische Untersuchungen in Bündnerschiefern (III) Eclogae Geologicae Helvetiae 74, 1063-1072.

Péron-Pinvidic, G., Manatschal, G., 2009. The final rifting evolution at deep magmapoor passive margins from Iberia-Newfoundland: a new point of view. International Journal of Earth Sciences 98 (7), 1581-1597.

Péron-Pinvidic, G., Manatschal, G., Minshull, T.A., Sawyer, D.S., 2007. Tectonosedimentary evolution of the deep Iberia-Newfoundland margins: evidence for a complex breakup history. Tectonics 26, TC2011 (19 pp.).

Péron-Pinvidic, G., Manatschal, G., Gernigon, L., Gaina, C., 2010. The formation and evolution of crustal blocks at rifted margins: new insights from the interpretation of the Jan Mayen microcontinent. Central and North Atlantic Conjugate Margins Conference, LISBON2010 (Avalaible at: www.metododirecto.pt/CM2010/index.php/ vol/article/viewFile/105/57).

Preiswerk, H., Bossard, L., Grütter, O., Niggl, P., Kündig, E., Ambühl, E., 1934. Carta geologica delle Alpi Ticinesi fra Valle Maggia e Val Bleno 1:50000. Commissione Geologica Elvetica delle Scienze Naturali.

Probst, P., 1980. Die Bündnerschiefer des nördlichen Penninikums zwischen Valser Ta und Passo di San Giacomo. Beiträge zur Geologische Karte der Schweiz [N.F.], 153. $63 \mathrm{pp}$.

Ringgerberg, Y., Tommasi, A., Stampfli, G.M., 2001. The Jurassic sequence of the Niesen nappe in the region of Le Sépey-La Forclaz (Switzerland): witness of the Piemont rifting in the Helvetic paleogeographic domain. Bulletin de Géologie Lausanne 348.

Schardt, H., 1898. Les régions exotiques du versant Nord des Alpes Suisse. Préalpes du Chablais et du Stockhorn et les Klippes. Bulletin de la Societé Vaudoise de Sciences Naturelles 34, 113-219.

Schmid, S.M., Rück, P., Schreurs, G., 1990. The significance of the Schams nappes for the reconstruction of the paleotectonic and orogenic evolution of the Penninic zone along the NFP-20 East traverse (Grisons, eastern Switzerland). In: Roure, et al. (Ed.), Deep structure of the Alps: Mémoire de la Société de France, Paris, 156, pp. 263-287.

Schmid, S.M., Pfiffner, O.A., Froitzheim, N., Schönborn, G., Kissling, E., 1996 Geophysical-geological transect and tectonic evolution of the Swiss-Italian Alps. Tectonics 15, 1036-1064.

Schroeder, W.J., 1939. La brèche du Chablais entre Giffre et Drance et les roches eruptives des Gets. Thèse $\mathrm{N}^{\circ} 1004$, Faculté des Sciences de l'Université de Genève. 138pp.

Sengör, C.A.M., Bernoulli, D., 2011. How to stir a revolution as a reluctant rebel: Rudolf Trümpy in the Alps. International Journal of Earth Sciences 100 (5), 899-936.

Septfontaine, M., 1983. Le Dogger des Préalpes médianes suisses et françaises (Stratigraphie, évolution paléogéographique et paléotectonique). Mémoires de la Société Helvétique des Sciences Naturelles 97, 1-121.

Simon, N.S.C., Podladchikov, Y.Y., 2008. The effect of mantle composition on density in the extending lithosphere. Earth and Planetary Science Letters 272, 148-157.

Spicher, A., 1980. Tektonische Karte der Schweiz, 1 : 500'000. Schweizerische Geologische Kommission, Bern.

Stampfli, G.M., 1993. Le Brianconnais: terrain exotique dans les Alpes? Eclogae Geologicae Helvetiae 86, 1-45. 
Stampfli, G.M., Borel, G.D., Marchant, R., Mosar, J., 2002. Western Alps geological constraints on western Tethyan reconstructions. Journal of the Virtual Explorer 8, 77-106.

Steck, A., 2008. Tectonics of the Simplon massif and Lepontine gneiss dome: deformation structures due to collision between the underthrusting European plate and the Adriatic indenter. Swiss Journal of Geosciences 101 (2), 515-546.

Steinmann, M., 1994. Die nordpenninischen Bündnerschiefer der Zentralalpen Graubündens: Tektonik, Stratigraphie und Beckenentwicklung. Unpublished PhD Thesis, ETH Zürich, 220 pp.

Steinmann, M., Stille, P., 1999. Geochemical evidence for the nature of the crust beneath the eastern North Penninic basin of the Mesozoic Tethys ocean. Geologische Rundschau 87, 633-643.

Tarasewicz, J.P.T., Woodcock, N.H., Dickson, J.A.D., 2005. Carbonate dilation breccias: examples from the damage zone to the Dent Fault, northwest England. Geological Society of America Bulletin 117, 736-745.

Thélin P., 1982. Les gneiss oeillés de la nappe du Grand-St-Bernard. Thèse Univ. Lausanne, $484 \mathrm{pp}$.

Trommsdorff, V., 1966. Progressive Metamorphose kieseliger Karbonatgesteine in den Zentralalpen zwischen Bernina und Simplon. Schweizerische Mineralogische und Petrographische Mitteilungen 46, 431-460.

Trommsdorff, V., 1990. Metamorphism and tectonics in the Central Alps: the Alpine lithospheric mélange of Cima Lunga and Adula. Memorie della Societa Geologica Italiana 45, 39-49.

Trümpy, R., 1945. Le Lias autochtone d'Arbignon (Groupe de la Dent de Morcles). Eclogae Geologicae Helvetiae 38 (2), 421-429.

Trümpy, R., 1949. Der Lias der Glarner Alpen. Denkschr. Schweiz. Nat.forsch. Ges 79 (1), 1-192.

Trümpy, R., 1951. Sur les racines helvétiques et les "schistes lustrés» entre le Rhône et la vallée de Bagnes (région de la Pierre Avoi). Eclogae Geologicae Helvetiae 42, 338-347.

Trümpy, R., 1954. La zone de Sion-Courmayeur dans le haut Val Ferret valaisan. Eclogae Geologicae Helvetiae 47 (2), 315-359.

Trümpy, R., 1958. Remarks on the pre-orogenic history of the Alps. Geologie en Mijnbouw 10, 340-352.

Trümpy, R., 1965. Zur geosynklinalen Vorgeschichte der Schweizer Alpen. Umschau Wiss Techn 65, 573-577.

Trümpy, R., 1966. Considérations générales sur le "Verrucano" de Alpes Suisses. Symposium sul Verrucano. Società Toscana di Scienze Naturali, Pisa, pp. 212-232.
Trümpy, R., 1975. Age and location of Mesozoic scarp breccias in the Alps. 9ème Congrès International de Sédimentologie, Nice, Thème, 4, pp. 313-318.

Trümpy, R., 1976. Du Pèlerin aux Pyrénées. Eclogae Geologicae Helvetiae 69 (2), 249-264.

Uhr, A., unpublished. Geologische Untersuchungen im Gebiet des Piz Terri. Unpubl. report ETHZ, 73 pp (deposited at BWG Bern-Ittingen).

Van der Plas, L., 1959. Petrology of the Northern Adula Region, Switzerland, (with particular reference to glaucophane-bearing rocks). Leidse Geologische Mededelingen $24,415-602$.

Vening Meinesz, F.A., 1950. Les "grabens" africains, resultat de compression ou de tension dans la croute terrestre? Institut Royal Colonial Belge, Bulletin des Séances 21, 539-552.

Wenk, E., 1970. Zur Regionalmetamorphose und Ultrametamorphose im Lepontin. Fortschritte der Mineralogie 47, 34-51.

Wernicke, B., 1985. Uniform-sense normal simple shear of the continental lithosphere. Canadian Journal of Earth Sciences 22 (1), 108-125.

Whitmarsh, R.B., Manatschal, G., Minshull, T.A., 2001. Evolution of magma-poor continental margins from rifting to seafloor spreading. Nature 413 (6852), 150-154.

Wiederkehr, M., Bousquet, R., Schmid, S.M., Berger, A., 2008. From subduction to collision: thermal overprint of HP/LT meta-sediments in the north-eastern Lepontine Dome (Swiss Alps) and consequences regarding the tectono-metamorphic evolution of the Alpine orogenic wedge. Swiss Journal of Geosciences 101 (Suppl. 1), 127-155.

Wiederkehr, M., Sudo, M., Bousquet, R., Berger, A., Schmid, S.M., 2009. Alpine orogenic evolution from subduction to collisional thermal overprint: the $40 \mathrm{Ar} / 39 \mathrm{Ar}$ age constraints from the Valaisan Ocean, Central Alps. Tectonics 28, 1-28.

Wiederkehr, M., Bousquet, R., Ziemann, M.A., Berger, A., Schmid, S.M., 2011. 3-D assessment of peak-metamorphic conditions by Raman spectroscopy of carbonaceous material: an example from the margin of the Lepontine dome (Swiss Central Alps). International Journal of Earth Sciences 100 (5), 1029-1063.

Wyss R., Isler A., 2007. Blatt 1234 Vals, Erläuterungen. Geol. Atlas Schweiz 1: 25000 , 121. Swisstopo, 78 pp.

Zulbati, F., 2008. Structural and metamorphic evolution of the phengite-bearing schists of the northern Adula Nappe (Central Alps, Switzerland). Geological Journal 43, 33-57. 